\title{
Mobile Melt-Dilute Technology Development Project FY 2005 Test Report
}

January 2006

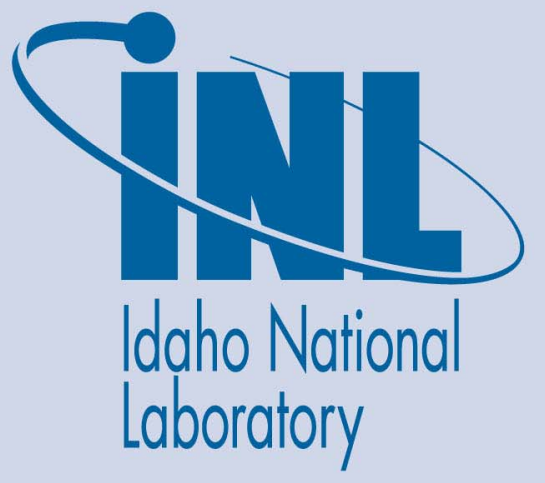

The INL is a U.S. Department of Energy National Laboratory operated by Battelle Energy Alliance 
INL/EXT-06-01126

\title{
Mobile Melt-Dilute Technology Development Project FY 2005 Test Report
}

\author{
Idaho National Laboratory \\ Savannah River National Laboratory
}

January 2006

Prepared for the

Office of Global Nuclear Materials Threat Reduction

(NA-212)

Under DOE Idaho Operations Office

Contract DE-AC07-05ID14517 
MOBILE MELT - DILUTE

\title{
TECHNOLOGY DEVELOPMENT PROJECT
}

\section{FY 2005 TEST REPORT}

\author{
INL/EXT-06-01126 \\ Revision 0 \\ January 19, 2006 \\ Prepared for \\ Office of Global Nuclear Materials Threat Reduction \\ (NA-212)

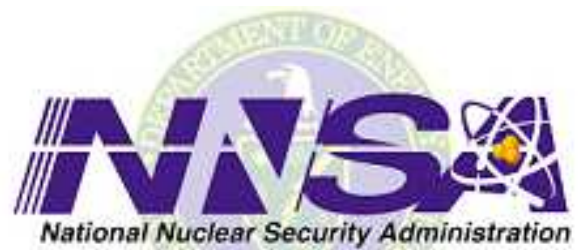

Prepared By:

Idaho National Laboratory and Savannah River National Laboratory
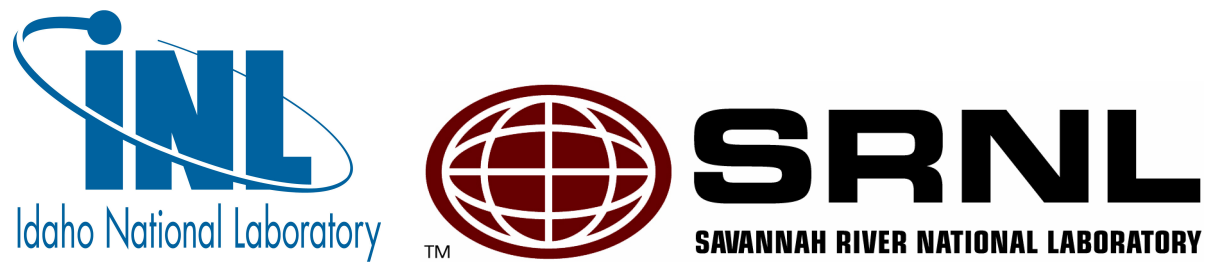
Table of Contents

$\begin{array}{lll}1.0 & \text { SUMMARY } & 1\end{array}$

2.0 INTRODUCTION

$\begin{array}{llr}\text { 3.0 SCOPE } & 2\end{array}$

$\begin{array}{llr}4.0 & \text { TESTS } & 2\end{array}$

4.1 CANISTER CONNECTION PORT 2

4.2 CANISTER QUALIFICATION TESTING 5

$\begin{array}{lll}4.3 & \text { FURNACE FUNCTION } & 12\end{array}$

$\begin{array}{lll}4.4 & \text { FUEL DRYING } & 15\end{array}$

4.5 TEMPERATURE CORRELATION 18

4.6 MELT STIRRING / INTEGRATED SYSTEM 22

$\begin{array}{lll}5.0 & \text { CONCLUSION } & 25\end{array}$

6.0 REFERENCES

$\begin{array}{llr}7.0 & \text { TESTING PHOTOS } & 27\end{array}$ 


\subsection{SUMMARY}

The adaptation of Melt-Dilute technology to a mobile and deployable platform progressed with the installation of the prototype air-cooled induction furnace and power generator in an ISO cargo container. Process equipment tests were conducted in FY'05 on two fronts: the melt container and its associated hardware and the mobile furnace and generator. Container design was validated through tests at elevated temperature and pressure, under vacuum, and subjected to impact. The Mobile Melt-Dilute (MMD) furnace and power source tests were completed per the plan. The tests provided information necessary to successfully melt and dilute HEU research reactor fuel assemblies.

\subsection{INTRODUCTION}

The Idaho National Laboratory (INL) and Savannah River National Laboratory (SRNL) MMD project team proposed the use of Melt-Dilute technology to render Russian research reactor fuel into a non-proliferable form and reduce global threat. The primary focus of this team's effort was to adapt melt-dilute technology for the sole purpose of making a non-proliferable form i.e. without its volume reduction capability. Adapting Melt-Dilute technology to a standardized mobile platform would allow multi-mode transportation (ship, rail, truck) to target locations. The project leveraged the experience of personnel from both laboratories to successfully produce a comprehensive conceptual design, forming the basis for design development and testing, and assembly of the actual hardware.

The MMD process is designed to treat spent research reactor fuel of Russian origin. The process simply melts aluminum-based research reactor fuel assemblies. Addition of depleted uranium to dilute the $\mathrm{U}_{235}$ content to less than $20 \%$ of total uranium enables conversion of the high-enricheduranium (HEU) nuclear material into a non-proliferable form. The MMD process being pursued by the joint INL-SRNL team is a closed process, with no ventilation or filtration necessary during melting and solidification. This is in contrast to SRNL's MMD-VR process which also effects volume reduction.

Research reactor fuel assemblies will be placed in an aluminum basket which is loaded into a carbon steel liner for treatment. The liner will be housed in the stainless steel melt canister and seal welded prior to melting. The closed system MMD process will expose the canister, though evacuated, to fission product gases evolved at elevated temperatures. Calculations predict worst case pressures (with $100 \%$ of fission product gases evolved) of approximately 57 psia. indicating the necessity of a vessel designed for temperature and pressure. The project requirement to supply a vessel meeting recognized standards led to a reduction in process temperature. Uranium-Aluminum fuel production experience at the Savannah River Plant (SRP) indicated process temperatures $100^{\circ} \mathrm{C}$ above liquidus (superheating) generate suitable product in an open system. Tests at SRNL [2] confirmed that less superheating to reduce the process temperature significantly reduced the dissolution rate of uranium in molten aluminum, indicating agitation of the molten fuel and diluent was necessary to keep process times low. This may be achieved by magnetic agitation. 
The melter is at the core of the MMD technology. The melter is an air-cooled induction furnace called a Direct Electric Heat (DEH) furnace. This proprietary vendor design eliminated the issues related to water, normally used to cool induction furnace power supplies and coils. The issues include: potential for criticality (water is a moderator), steam generation (if water contacts hot surfaces), and the large equipment necessary to circulate, monitor, and control cooling water. The air-cooled DEH furnace is substantially smaller than water-cooled induction furnaces of similar power, making it suitable for installation in a small, mobile container.

The MMD team conducted scoping tests using a DEH furnace at the manufacturer's R\&D facility, under a SRNL contract. The team used a prototype of the fuel-melting canister and instrumented mock fuel assemblies to verify the application of DEH furnace technology to the MMD process. The tests successfully demonstrated this application. Modifications to the DEH furnace, tailoring it to MMD process were identified by the MMD team and manufacturer's technical staff. Magnetic agitation, a smaller diameter coil, and remote control were some of the necessary modifications made to produce the desired result. SRNL subsequently procured a prototype DEH furnace with the modifications to support the FY05 MMD system tests.

INL completed revisions to the designs of the canister, liner and fuel basket in FY'05 [1]. The canister-liner components were fabricated at the INL to enable prototype furnace tests at SRNL and the canister qualification test. INL also contracted for the design and fabrication of pneumatic canister and liner lifting tools needed for testing.

SRNL procured a 40 foot, high-cube, ISO cargo container with specified modifications for the MMD demonstration. The cargo container was placed on an asphalt pad at SRNL isolated from all services. A $200 \mathrm{~kW}$ diesel generator was installed in one compartment of the container, followed by tracks, and a powered cart for the prototype furnace. The furnace was installed on the cart and wired directly to the generator. The completion of these tasks prepared the MMD prototype process module for the system tests planned for FY05.

\subsection{SCOPE}

This report covers separate tests of the canister connection port, canister design, furnace functions, temperature correlation, fuel drying, and melt stirring. This report presents information from each test, discusses its purpose, the general procedure to conduct it, the results, and how they apply. An integrated system test of the prototype components was performed as the final test in the FY'05 series. The tests involved processing surrogate fuel through the complete drying and melt sequence. Previous test results helped establish the conditions of the MMD integrated system test.

\subsection{TESTS}

\subsection{CANISTER CONNECTION PORT}

The purpose of the canister connection port testing was to qualify the canister quick disconnect fitting for use on the MMD canister as described in the Test Plan [3]. The quick disconnect fitting is used to connect the vacuum drying system to the canister. Connection to the canister is made at room temperature but disconnection is made when the canister and contents are at 
$500^{\circ} \mathrm{C}$. A vacuum needs to be maintained inside the canister during the drying operation and after the connection port on the canister is disconnected. This qualification test was to determine whether the quick disconnect fitting meet the performance requirements.

Several sets of prototype quick disconnect fittings were obtained from the Staubli Corporation. These quick disconnect fittings were designed for $500^{\circ} \mathrm{C}$ and vacuum conditions. In addition, the quick disconnect fittings were designed to maintain a vacuum inside the canister following fuel drying while the canister is at $500^{\circ} \mathrm{C}$. The quick disconnect fittings are shown in Figure 1. Two type of quick disconnect fittings were supplied by Staubli. One was the traditional push button fitting, shown on the right, and the other was a screw type of fitting, shown on the left.

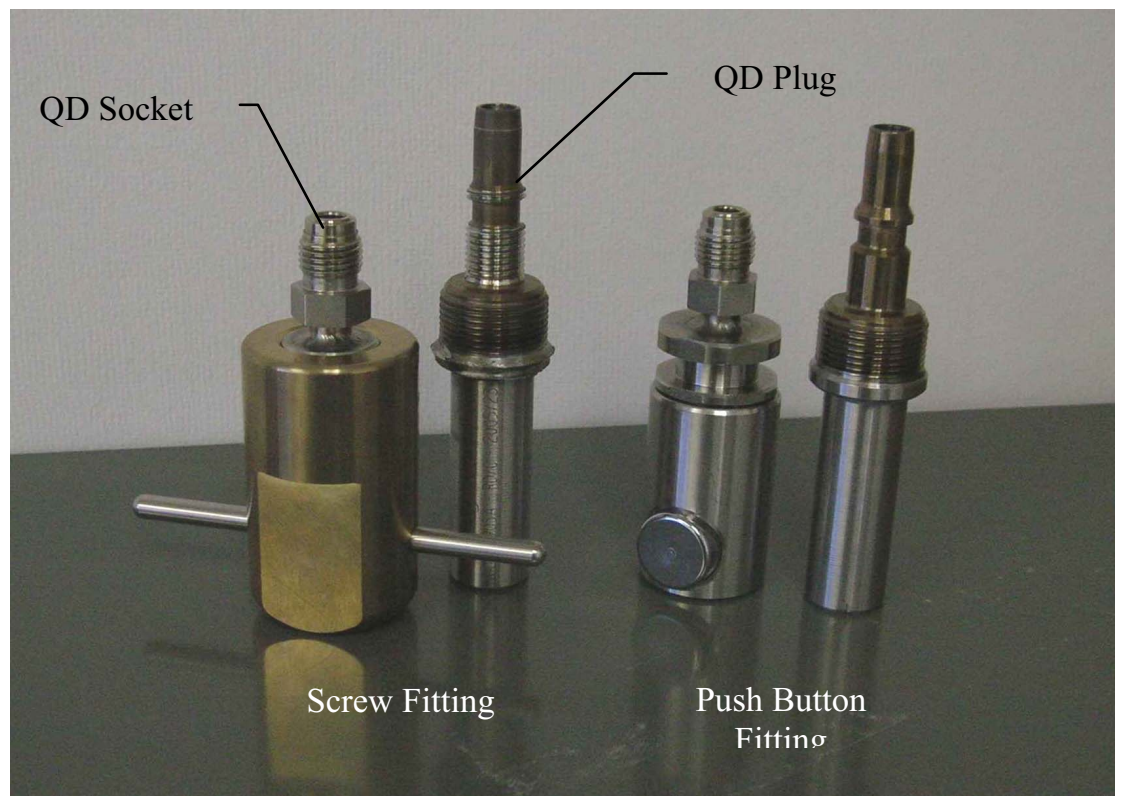

Figure 1 Quick Disconnect Fittings

The plug ends of both types of quick disconnect fittings were installed on separate test chambers as shown in Figure 2. A pre-test helium leak check $\left(<1 \times 10^{-6} \mathrm{cc} / \mathrm{sec}\right)$ was performed on each test chamber to ensure it did not have any leaks. During this pre-test helium leak check it was determined that both plug ends of the quick disconnect fitting were leaking. Several unsuccessful attempts were made to seal the plug ends, including taking the plug ends apart and performing a thorough cleaning of all surfaces. Two plug ends, which had not been installed, were then leak tested to determine if the problem with the plug ends might have occurred during the installation on the test chambers. Both of these plug ends also failed the leak test eliminating the possibility of improper installation. Further testing of the quick disconnect fittings was not possible and the manufacturer was notified of the problem with the plug ends of the quick disconnect fittings.

If the test chamber with quick disconnect fittings had passed the pre-test helium leak check, then the actual performance test would have been performed. The performance test would have consisted of placing the test chamber inside a furnace and connecting a vacuum pump to the quick disconnect. A vacuum ( $<200$ millitorr) would have been pulled on the test chamber as it was heated up to approximately $500^{\circ} \mathrm{C}$. A vacuum gauge would have monitored the pressure 
inside the test chamber during the test. After the test chamber had been held at the testing conditions for one hour, the furnace would then have been turned off and the vacuum line disconnected from the canister quick disconnect. The pressure inside the canister would then have been monitored to determine if any leakage occurs. The test setup is shown on Figure 3.

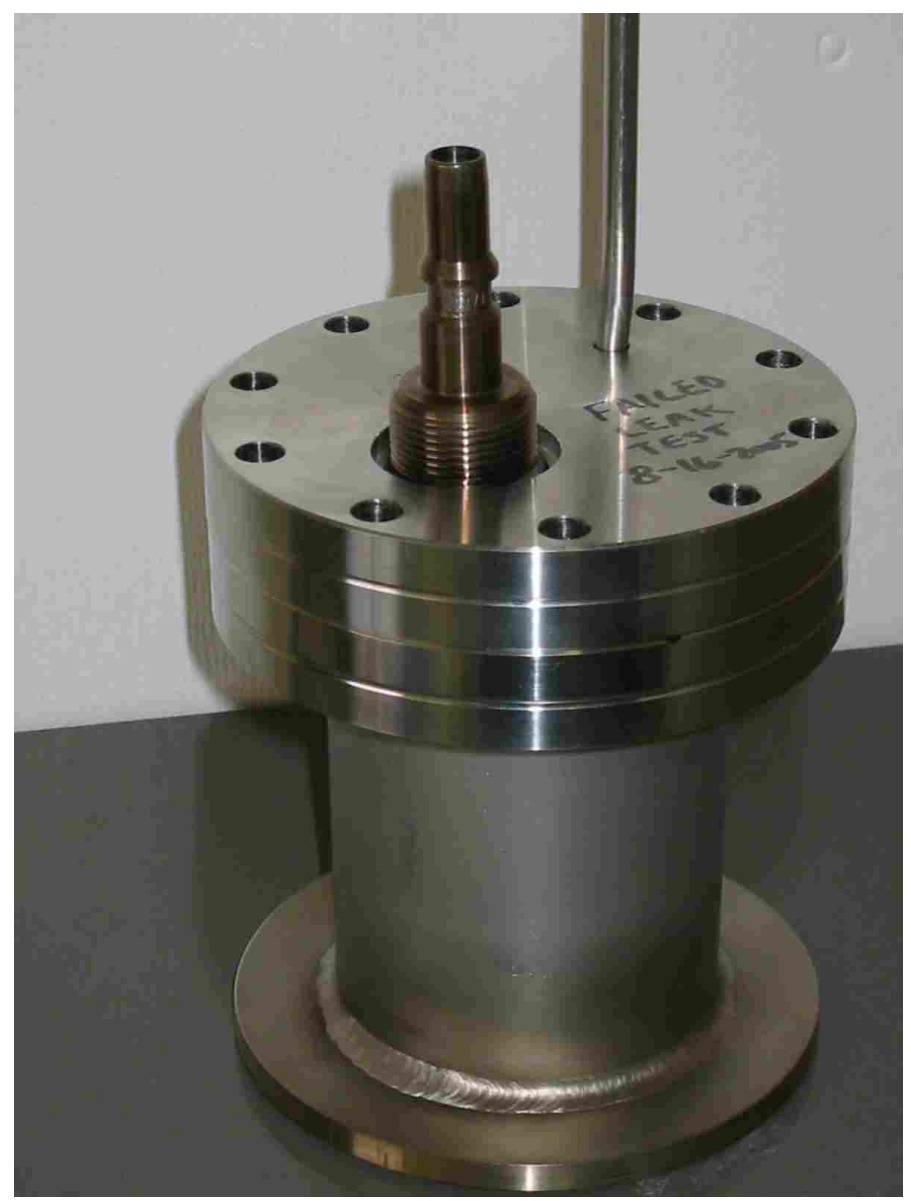

Figure 2 Quick Disconnect installed on Test Chamber 


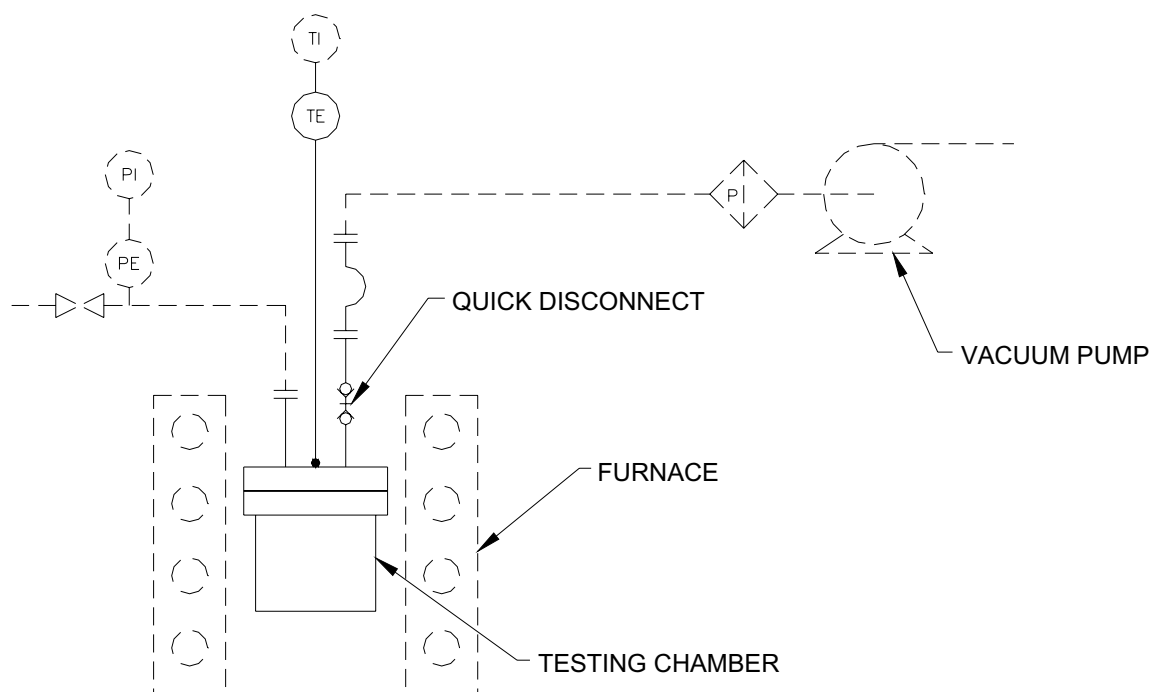

Figure 3 Quick Disconnect Fitting Test Setup

The plug ends of the quick disconnect fittings failed the pre-test helium leak check so testing under MMD process drying conditions could not be performed. The quick disconnect manufacturer was notified of the defects with the prototypes and is in the process of evaluating the quick disconnect fitting design. Further evaluation of the quick disconnects in the future will be necessary.

The design temperature $\left(500^{\circ} \mathrm{C}\right)$ for the quick disconnect fittings is pushing the envelope for valve seals. There is the possibility that the manufacturer may not be able to remedy the problems with the prototypes and it may become necessary to pursue one of the alternatives to quick disconnect fitting identified in the Canister Connection Port Options Study [4].

\subsection{CANISTER QUALIFICATION TESTING}

Canister qualification testing was completed as discussed in the Test Plan [3]. The purpose of the testing was to verify the design and performance of the prototype MMD canister for the combination of the design loads for the drying, melting, and diluting process steps specified in the Prototype Canister Design document [1]. The prototype MMD canister functions as the process vessel to dry, melt and dilute spent research reactor fuel while containing all fission products released during the melt and dilute process.

A MMD prototype canister was fabricated in accordance with the design specified in the Prototype Design document [1]. Approximately $132 \mathrm{lbs}$ of clean scrap aluminum was loaded into the canister to simulate the mass of the spent research reactor fuel assemblies and the aluminum basket. 
The qualification testing consisted of subjecting a prototype canister to specific combinations of the design loading conditions. The design load conditions consisted of:

1) design temperature $\left(\mathrm{T}_{\mathrm{D}}\right)$ of $815^{\circ} \mathrm{C}$,

2) maximum design pressure $\left(\mathrm{P}_{\mathrm{D}}\right)$ of 57.3 psia,

3) minimum design pressure $\left(\mathrm{P}_{\min }\right)$ of full vacuum,

4) weight of components and contents $(\mathrm{W})$,

5) post $\mathrm{MMD}$ processing canister pressure $\left(\mathrm{P}_{\mathrm{C}}\right)$ of 0 psig after the canister has cooled to $<100{ }^{\circ} \mathrm{C}$, and

6) vertical drop (D) of seven feet to simulate a lifting and handling accident following MMD processing

The specific load combinations tested were: 1) $\left.T_{D}+P_{D}+W, 2\right) T_{D}+P_{\min }+W$, and 3) $W+D+P_{C}$.

The canister was placed inside a resistance type furnace in order to test the canister for load combinations 1 and 2. A port on the canister lid allowed the canister to be connected to a test manifold, which consisted of a vacuum line, an argon line, two independent pressure relief valves, and two independent calibrated pressure gauges. Figure 4 shows the test manifold and the instrumentation setup. Canister pressurization was accomplished via a standard welding grade argon bottle with stainless steel tubing and fittings. Figures 5 and 6 show the canister prior to the heat-up test.

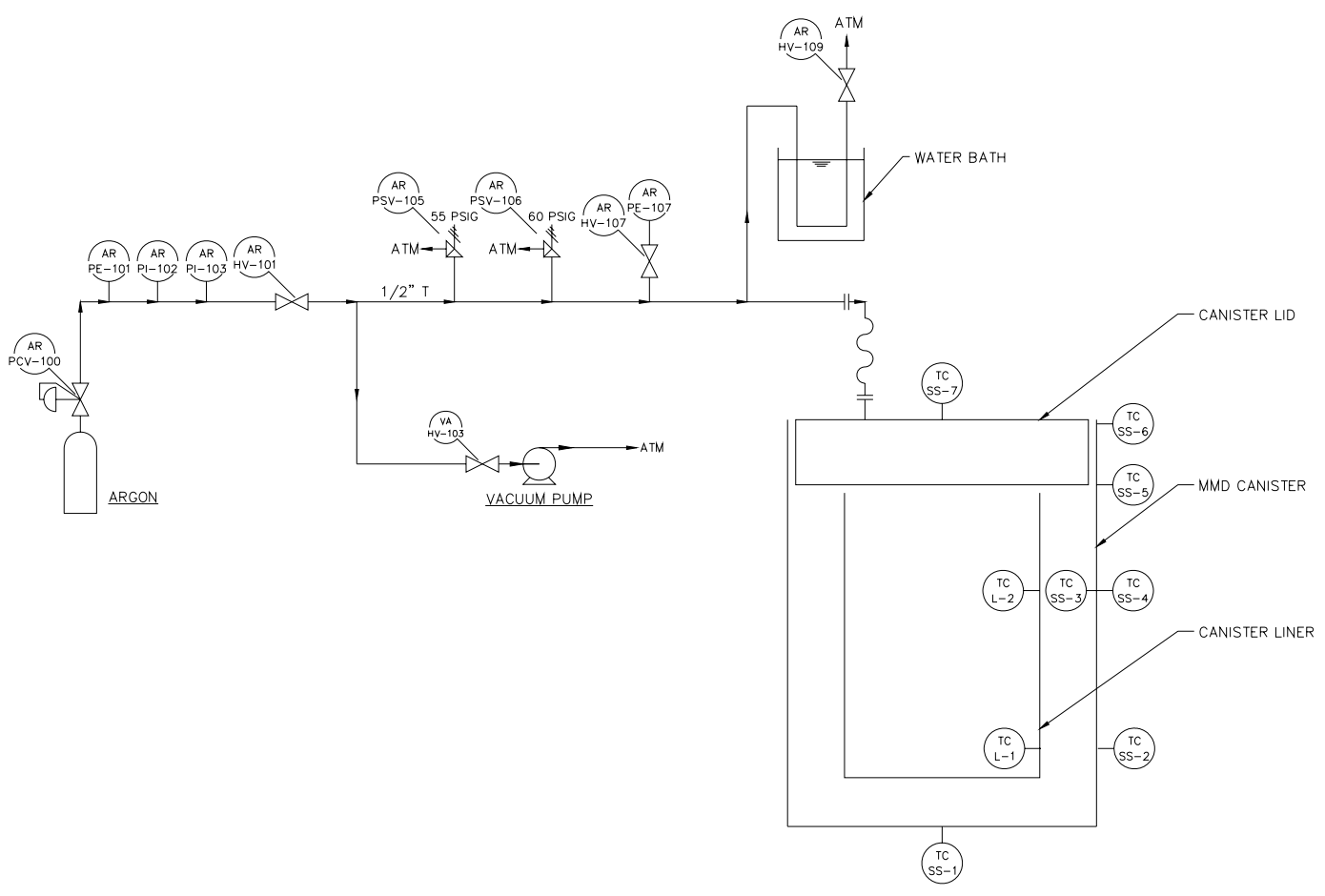

Figure 4 MMD Canister Test Setup 


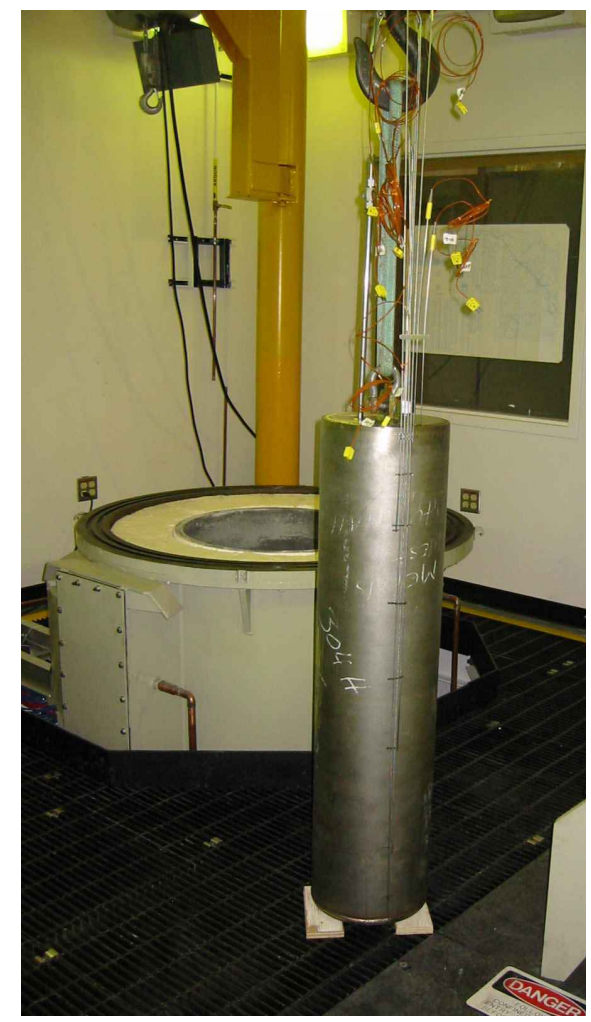

Figure 5 MMD Canister

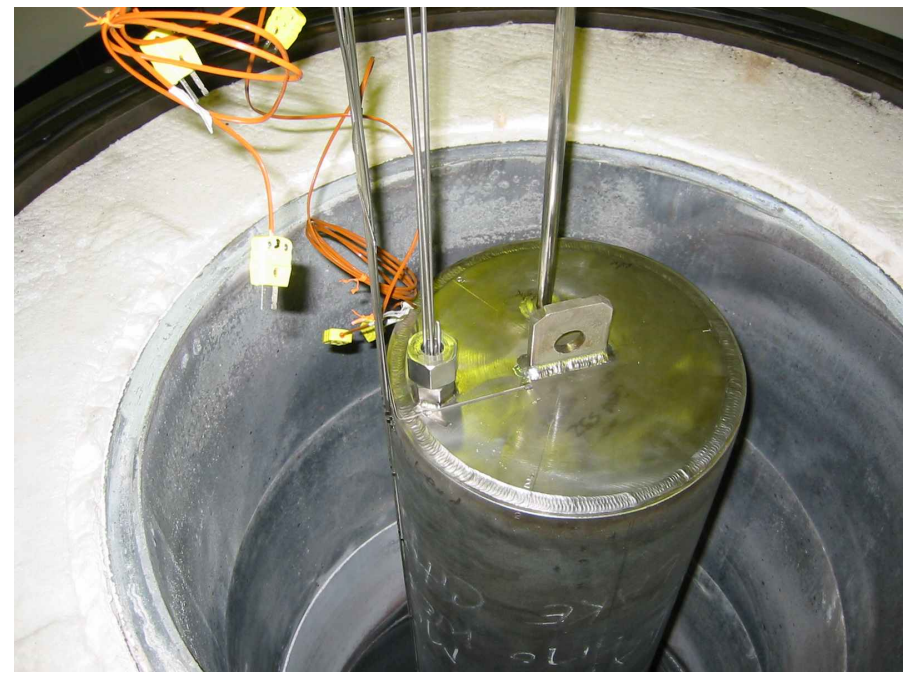

Figure 6 MMD Canister in Furnace

The canister test progressed as follows:

1) The canister welds were $100 \%$ visual examined and then helium leak checked to $10^{-6} \mathrm{std} \mathrm{cc} / \mathrm{sec}$ using the helium hood method. All canister welds were then inspected with dye penetrant. Additionally, the longitudinal weld on the canister shell was $100 \%$ radiographically inspected during the fabrication process. Finally, the canister was dimensionally inspected at three longitudinal and three latitudinal locations. 
2) The canister was instrumented with eight (8) type $K$ thermocouples and then placed in the furnace. The thermocouple and vacuum/pressure data were recorded on a PC data acquisition system. The canister was evacuated to below 0.1 psia ( 5 Torr) and heated to $805 \pm 10^{\circ} \mathrm{C}$. The canister was held at these conditions for two hours. The heat-up of the canister under vacuum conditions is shown in Figure 7. Following the vacuum portion of the test, the canister was then gradually filled with argon to a pressure 40 psia. After a 5-minute hold at $40 \mathrm{psia}$, the canister was then pressurized in increments of approximately 7 psi. Between increments, the vessel pressure was held constant for approximately 5 minutes, to allow observation of significant gas leakage or obvious problems. The maximum test pressure was $63.0 \pm 2$ psia (1.1 times maximum allowable working pressure). The pressure was then reduced to $57.3 \pm 2$ psia (45.1 psig) and held at $805 \pm 10{ }^{\circ} \mathrm{C}$ for two hours. The pressure test is shown in Figure 8. Following the test, the canister pressure was bled off to approximately $1 \mathrm{~atm}$ and the canister was allowed to cool to room temperature. The canister was then removed from the furnace, visually inspected by the experimenter, and helium leak checked. The canister was also dimensionally inspected at three longitudinal and three latitudinal locations.

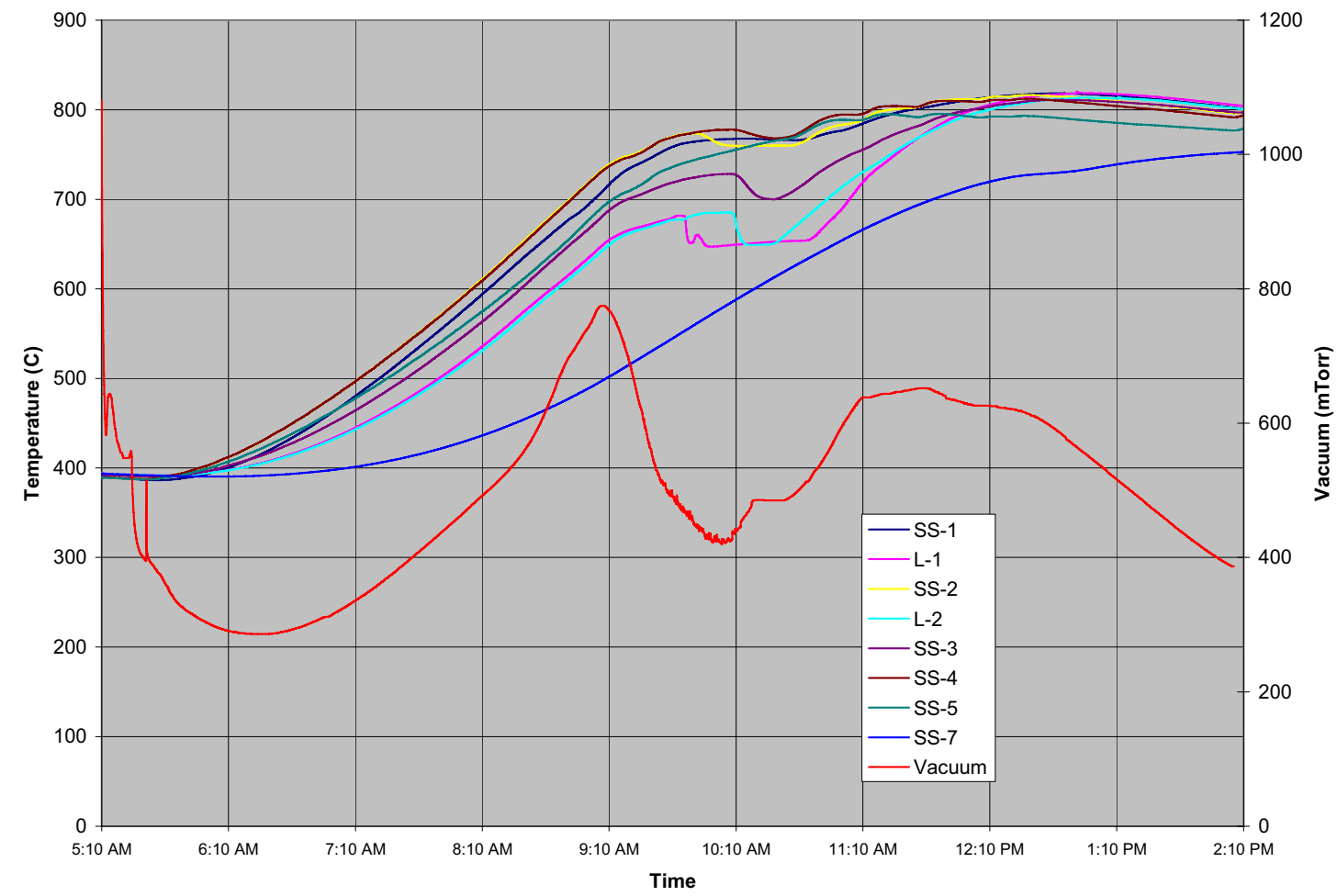

Figure 7 Vacuum/Temperature Test Data 


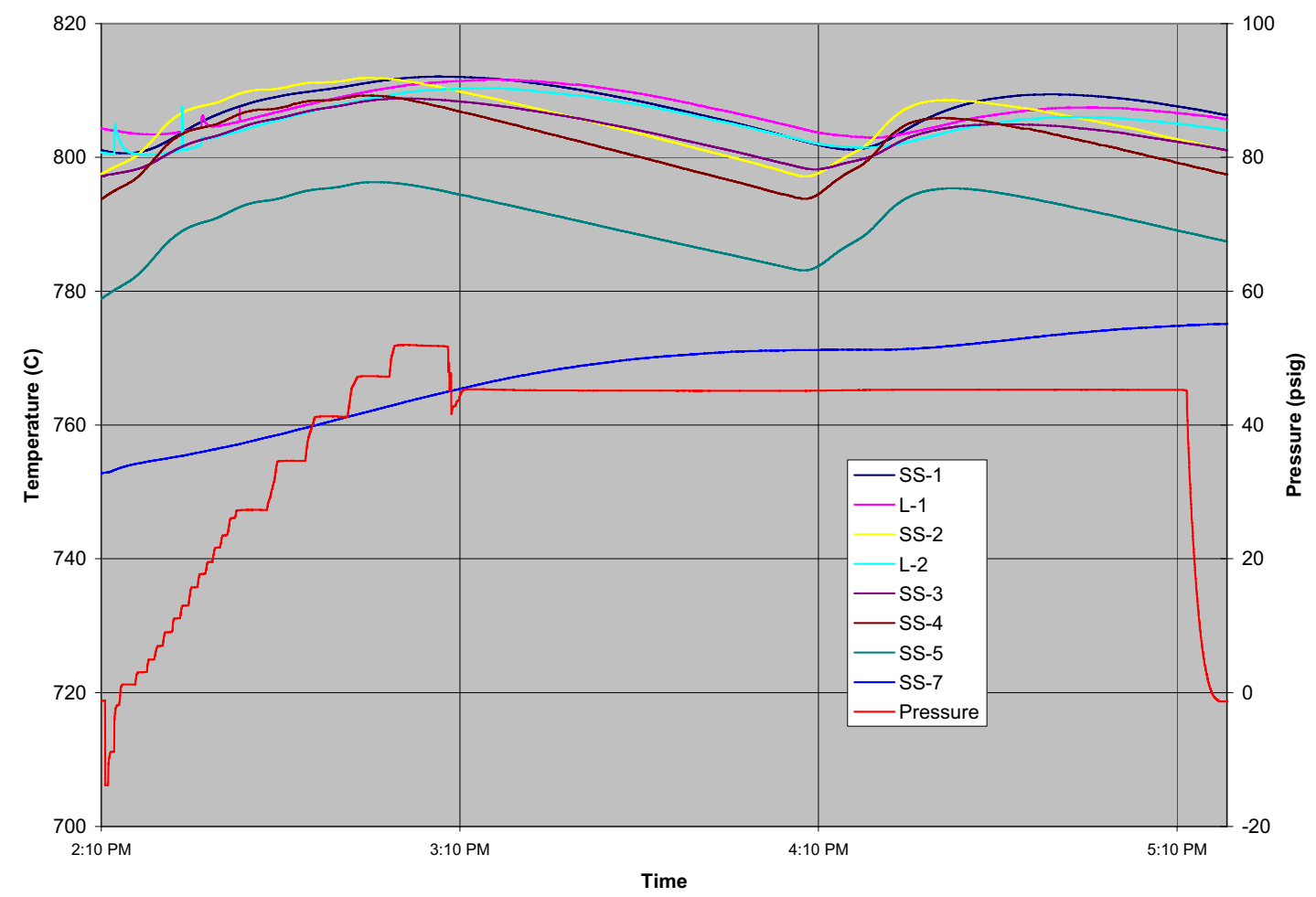

Figure 8 Pressure/Temperature Test Data

3) The canister was instrumented with one thermocouple, an accelerometer, vacuum gauge, and ten (10) strain gauges as shown in Figure 9 for the purpose of the Drop Test. The canister was evacuated to $<1$ Torr. The isolation valve on the canister port was closed just prior to the drop test. The canister was then lifted to a height of 7 feet above an unyielding surface and dropped. Post drop test inspections of the canister included a visual examination of the canister for obvious damage, a helium leak check, and dimensional inspections at the three longitudinal and three latitudinal locations. 


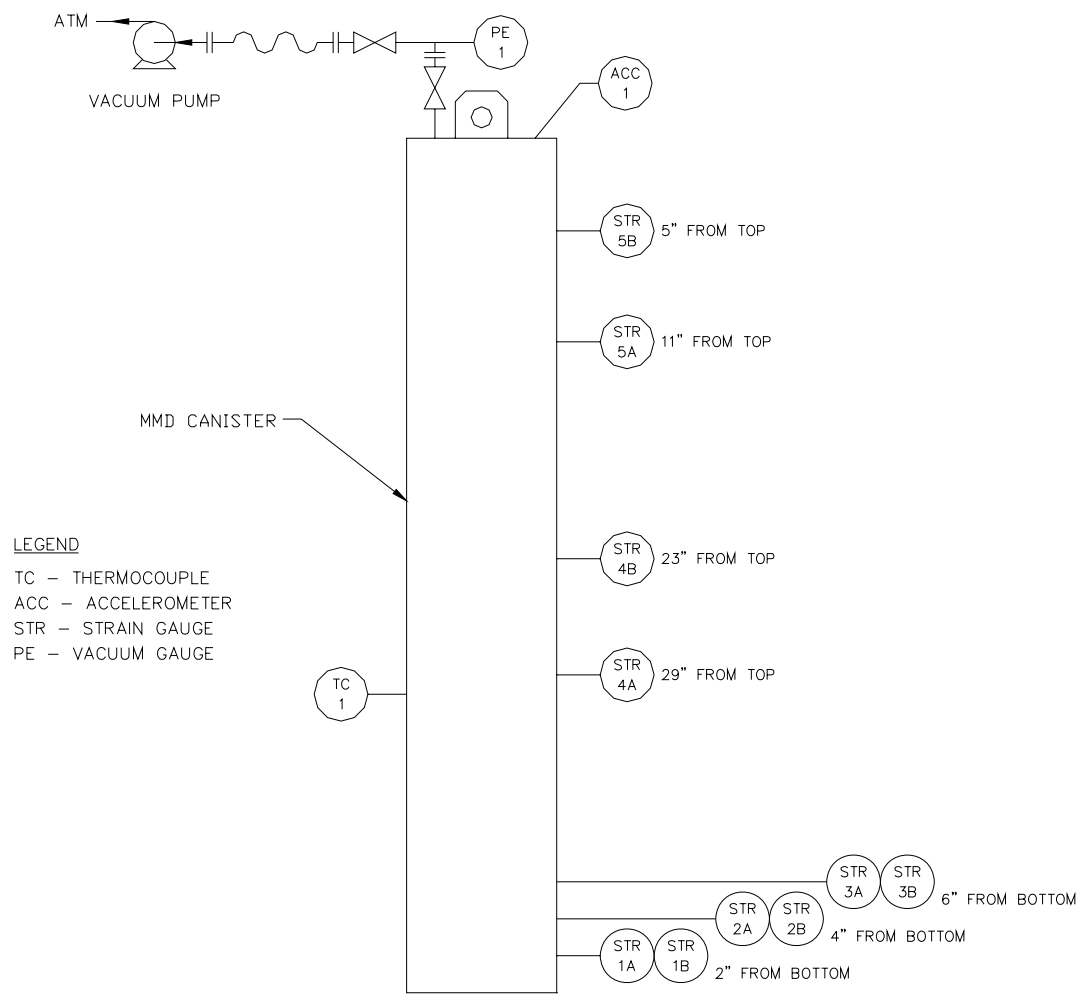

Figure 9 Drop Test Instrumentation

The canister performed as designed. The pre and post-helium leak checks shown in Table 1 for the temperature and vacuum/pressure portion of the qualification test indicate that the canister maintained its integrity and there was no loss of containment. The dimensional inspections shown in Tables 2 and 3 indicate there was no deformation of the canister from the temperature and pressure loads.

Table 1 Helium Leak Check Results

\begin{tabular}{|l|l|l|l|}
\hline & Pre-Heat Test & Post-Heat Test & Post Drop Test \\
\hline Helium Leak Check Results & $<1 \times 10^{-6} \mathrm{cc} / \mathrm{sec}$ & $<1 \times 10^{-5} \mathrm{cc} / \mathrm{sec}$ & $<1 \times 10^{-5} \mathrm{cc} / \mathrm{sec}$ \\
\hline
\end{tabular}


Table 2 Dimensional Inspection - Canister Diameter (inches)

\begin{tabular}{|l|l|l|l|}
\hline & \multicolumn{3}{|l|}{ Location \#1 } \\
\hline Location & Pre-Heat Test & Post-Heat Test & Post-Drop Test \\
\hline 6" from canister top & 11.250 & 11.238 & 11.234 \\
\hline Canister center elevation & 11.182 & 11.201 & 11.192 \\
\hline 6" from canister bottom & 11.192 & 11.208 & 11.202 \\
\hline & \multicolumn{3}{|l|}{} \\
\hline & $90^{\circ}$ to Location \#1 & \\
\hline & Pre-Heat Test & Post-Heat Test & Post-Drop Test \\
\hline 6" from canister top & 11.234 & 11.232 & 11.221 \\
\hline Canister center elevation & 11.218 & 11.214 & 11.210 \\
\hline 6" from canister bottom & 11.236 & 11.240 & 11.226 \\
\hline
\end{tabular}

Table 3 Dimensional Inspection - Canister Height (inches)

\begin{tabular}{|l|l|l|l|}
\hline Location & Pre-Heat Test & Post-Heat Test & Post Drop Test \\
\hline Circumferential Location \# 1 & 46.139 & 46.127 & 46.118 \\
\hline Circumferential Location \# 2 & 46.210 & 46.200 & 46.176 \\
\hline Circumferential Location \# 3 & 46.193 & 46.166 & 46.153 \\
\hline
\end{tabular}

The helium leak check of the canister following the drop test also indicates that the canister maintained its integrity and there was no loss of containment. The canister impacted on a concrete surface with a $\sim 480 \mathrm{~g}$ force as shown in Figure 10 and sustained no observable damage. The final dimensional inspection showed no significant permanent deformation. No weld failures were noted during a visual examination or during the helium leak check.

Performance of the canister for the three specified test load combinations was found to be acceptable. 


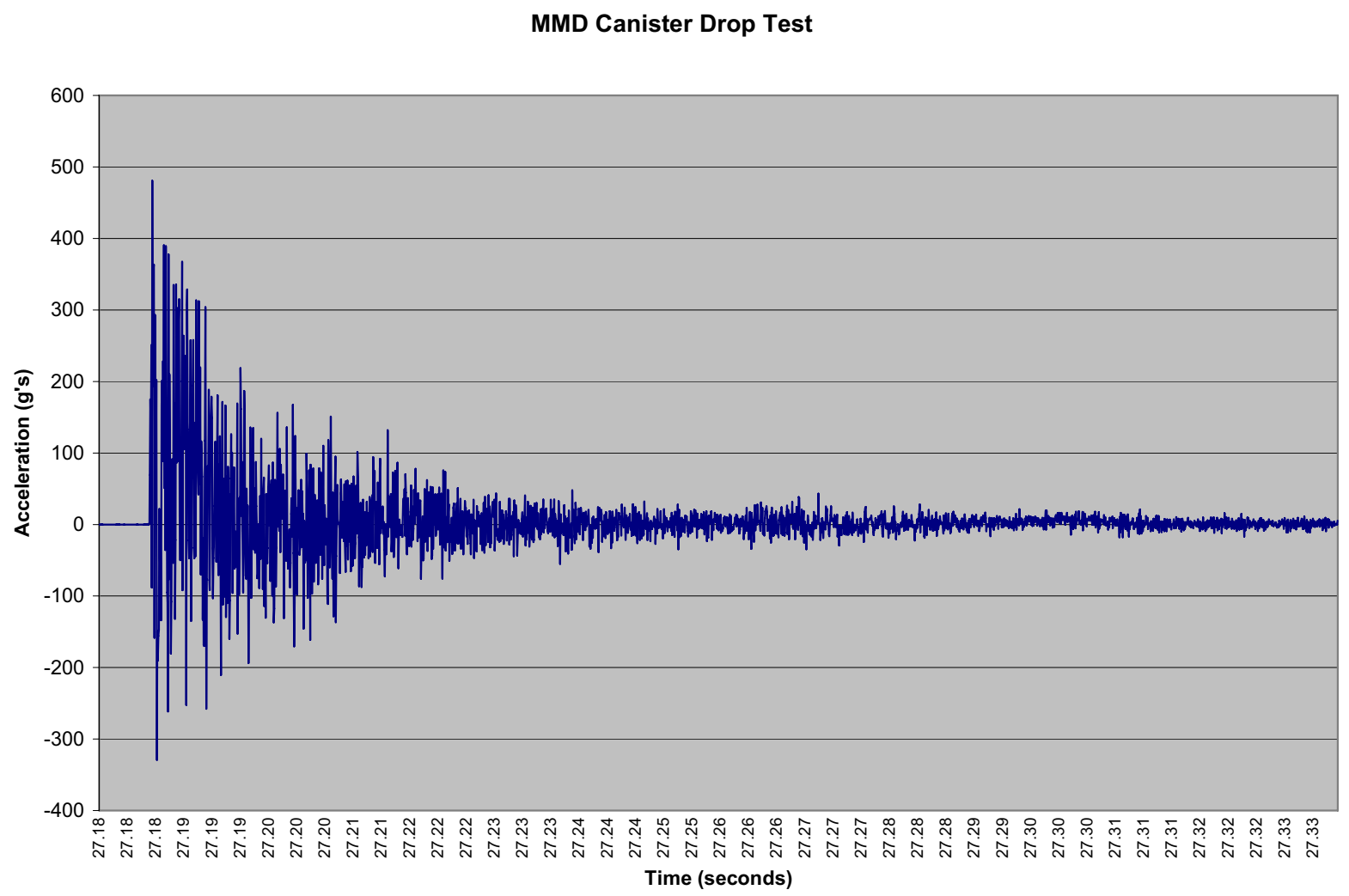

Figure 10 Drop Test Accelerometer Data

\subsection{FURNACE FUNCTION}

The MMD prototype furnace was installed in the ISO container at SRNL. Subsequently, the diesel generator was connected and the functional test completed as described in the Test Plan [3] with support from the furnace manufacturer's representative. The function of the generator, the electrical connections and the furnace cooling fan operations were also verified. A 5-hp squirrel-cage fan provides cooling air to electronic components and the furnace coil. Correct phase connections were also verified with an oscilloscope attached to the power supply. A baffle on the coil exhaust port restricts air flow and causes pressure from the fan to build up and actuate a pressure switch. This switch must be closed to allow high voltage power supply operation and the fan adjusts flow according to load on the power supply. These also functioned as designed. Figure 11 shows the layout of the MMD cargo container and its components. 


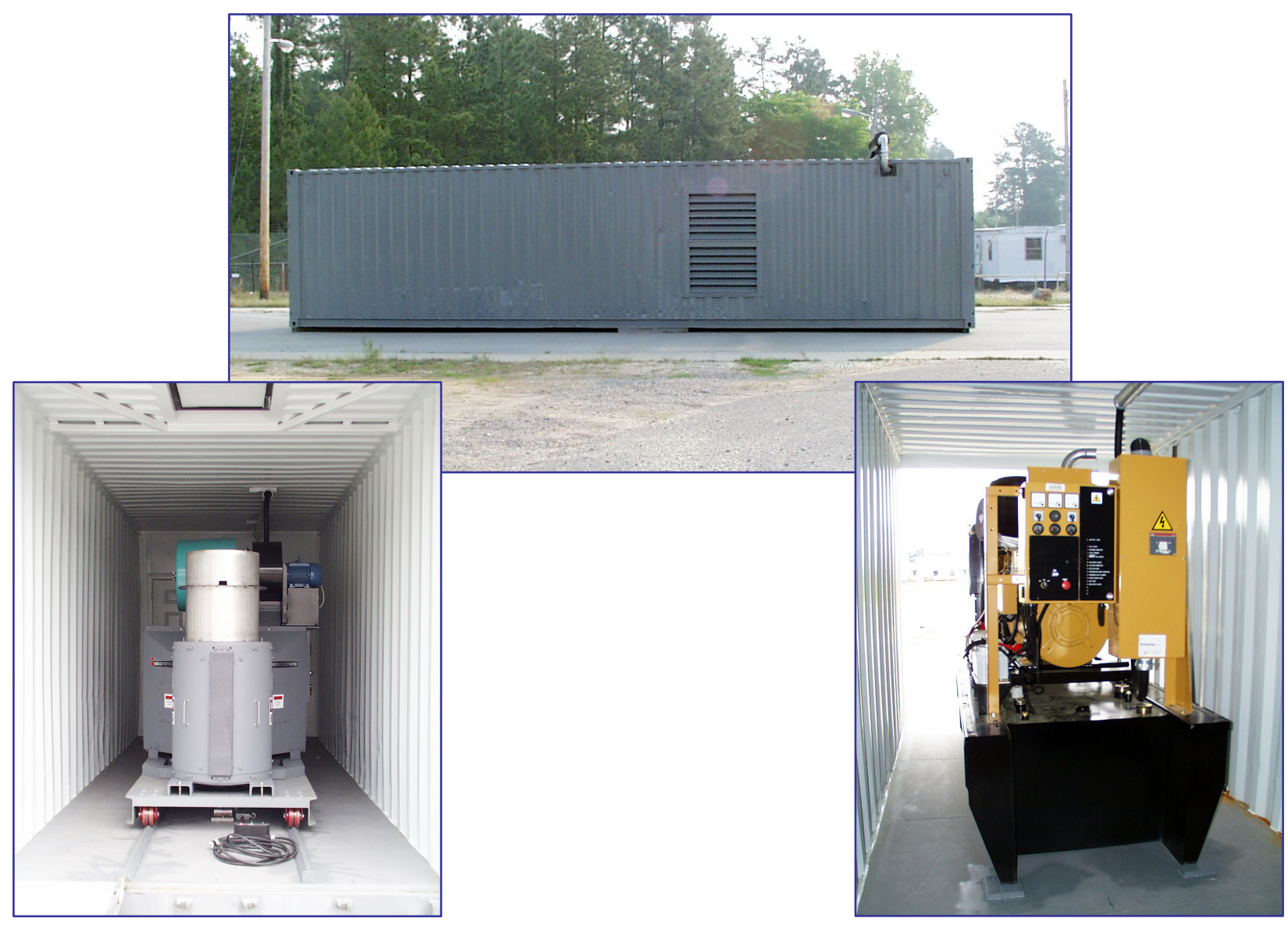

Figure 11 - MMD Cargo container, DEH Furnace, and Diesel Generator

A stainless steel canister, carbon steel liner, 1 mock IRT fuel assembly and 32 pounds of aluminum sheet were loaded into the furnace cavity. No cap was placed on the canister, but a graphite sleeve containing a type $\mathrm{K}$ thermocouple was inserted in the liner. Photographs of this equipment are shown in Figure 12. Control voltages were checked in the on-board and remote control panels, each met operational requirements. Jumpers in the programmable temperature controller were positioned to accommodate SRNL's preferred operating mode. Cooling fan and control circuits were checked and operating correctly, allowing the high voltage power supply to function. With these checks complete, the high voltage supply was activated and the remote control panel used to track furnace status. No error messages were encountered at this time.

Furnace power was controlled manually, in the Normal Mode, and was initially set at $50 \mathrm{~kW}$, followed by a slow increase in load temperature. A short time later the power was increased to $100 \mathrm{~kW}$, again followed by the proper load response. Power was adjusted up and down to check the response of the load to power variations and familiarize operators with the remote control panel. Manual control was used in all the furnace tests and power levels were recorded to evaluate the possibility of programming the required power sequence. It was also used to allow adjustments of furnace power to accomplish the goals of each test. The aluminum was molten in slightly less than a half hour and the furnace was switched from Normal Mode to Stirring Mode. 
DEH magnetic stirring is substantially different from conventional induction stirring technology. Standard water-cooled technology offered low frequency $(60 \mathrm{~Hz})$ stirring at adjustable power settings. However, a large (dedicated) power supply was most often used in addition to the high frequency power supply. These supplies were large and were not operated at the same time, employing various methods to transfer from one supply to the other. These involved manually switching large electrical contacts after the furnace load was molten. Some superheating of the metal was necessary since even the highest stirring power available (on standard units) didn't provide enough heat energy to maintain its temperature.

DEH magnetic stirring is unique because it uses the higher frequency coil power to stir, but modulates it at low frequency. The result is continued heating of the load while stirring is active, eliminating the necessity of significantly superheating the molten metal. This method eliminates the need for a separate power supply and the associated switching that goes with it. The elimination of significant superheating has the added benefit of decreasing the cooling time for the ingot. Stirring is controlled at the remote control panel and fits the requirements of MMD process operation. When the stirring mode was engaged, its effects were visually confirmed and power to the coil was turned off. These steps verified the furnace was capable of performing the functions required for the MMD process.

For the purposes of this test, the shield plug/lid was bolted to the container and the assembly was removed from the furnace to facilitate rapid solidification of the molten aluminum. The furnace controls and fan were left on until the interior of the furnace cavity was below $200^{\circ} \mathrm{C}$. This MMD prototype furnace functional test provided the basis to conduct the remaining furnace/load tests.

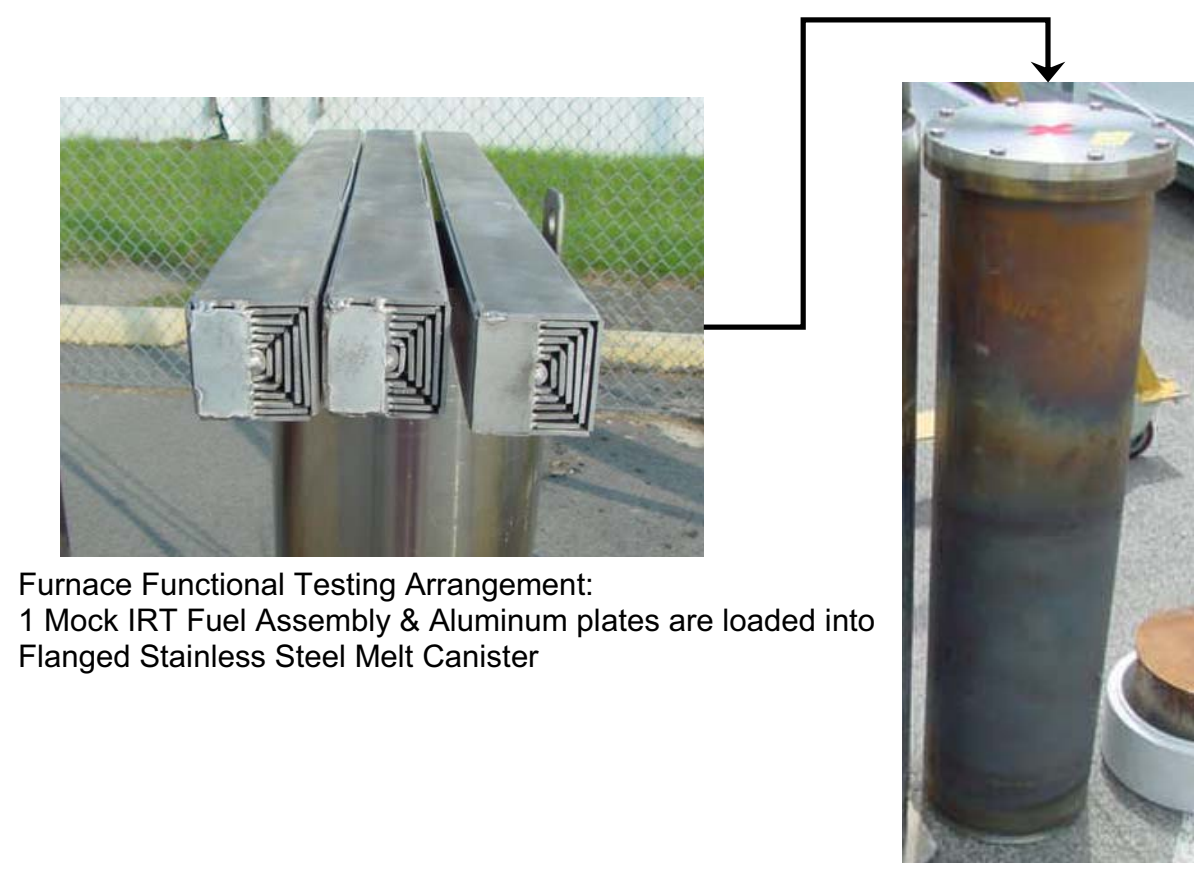

Figure 12 - Furnace Functional Test Equipment 


\subsection{FUEL DRYING}

The fundamental prerequisite of processing any reactor fuel in a closed system is the absence of water from the fuel. Any water remaining in the container after it is sealed will cause the container to be pressurized as the temperature is increased to melt and dilute the fuel. The Russian-origin spent fuels are typically stored underwater and, when they are removed, will have some liquid trapped in their interior and at least one form of hydrated oxide on their surfaces (formed in reactor exposure at temperatures above $80^{\circ} \mathrm{C}$ ). Extracting this water requires converting the water to vapor and evacuating the vapor from the processing container. Heating the fuel converts the water to vapor and applying a vacuum to the container provides the impetus to remove it. The liquid may be vaporized at $100^{\circ} \mathrm{C}$ but the chemical bond of hydrated oxides can only be broken at higher temperatures. Boehmite $\left(\mathrm{Al}_{2} \mathrm{O}_{3}-\mathrm{H}_{2} \mathrm{O}\right)$ requires higher temperatures than the other forms of hydrated aluminum oxide (bayerite and gibbsite). Decomposition of boehmite in a vacuum begins between 200 and $287^{\circ} \mathrm{C}$ [5] and is complete by $482^{\circ} \mathrm{C}$.

Since the temperature characteristics of boehmite destruction are known, removing the chemically bound water is a simple matter of bringing the furnace load to the correct temperature. Holding the fuel at that temperature for some period provides an extra measure to ensure that the water has been driven off and supplied to the evacuation system for removal. Instrumenting the furnace load (surrogate fuel assemblies) to verify temperature is one way to show the ability of the MMD prototype system to remove water. Another way to demonstrate this ability is to include aluminum with hydrated oxide coatings. SRNL used coupons with these oxides as part of the furnace load for this test.

The furnace load for this and subsequent tests, described in the Test Plan [3], used the updated MMD canister hardware design completed in FY'05 [1]. It also included a fused-silica crucible, with a 1 inch wall thickness, specified as a secondary container for the furnace load. The purpose of the test was to verify adequate fuel assembly heating during the drying process. The scoping test at the furnace manufacturer's R\&D facility indicated a range of temperatures in the fuel assemblies. Because the difference between the target drying temperature and the melting temperature is approximately $125^{\circ} \mathrm{C}$, this test was important to determine fuel assembly response to heating and necessary soak times while minimizing the possibility of melting the fuel. Volatile fission products, released when fuel assemblies melt, are meant to be retained in the sealed container, condensing in the container as it cools.

The furnace was loaded with a stainless steel canister (and shield plug), a carbon steel liner, an aluminum fuel basket (weighing approximately 65 pounds), and 4 mock Russian IRT fuel assemblies (weighing approximately 16 pounds each). One of the mock assemblies was instrumented with five type $\mathrm{K}$ thermocouples, positioned to provide temperatures on the assembly centerline at approximately 6 inch intervals from top to bottom. Additional thermocouples were positioned on the exterior skin of the canister and under the crucible to monitor their temperatures.

Aluminum coupons with surface oxides (retrieved from archives) were suspended next to, and laid on the top of, the fuel assemblies and the aluminum basket. These are shown in Figure 13 prior to the test. 

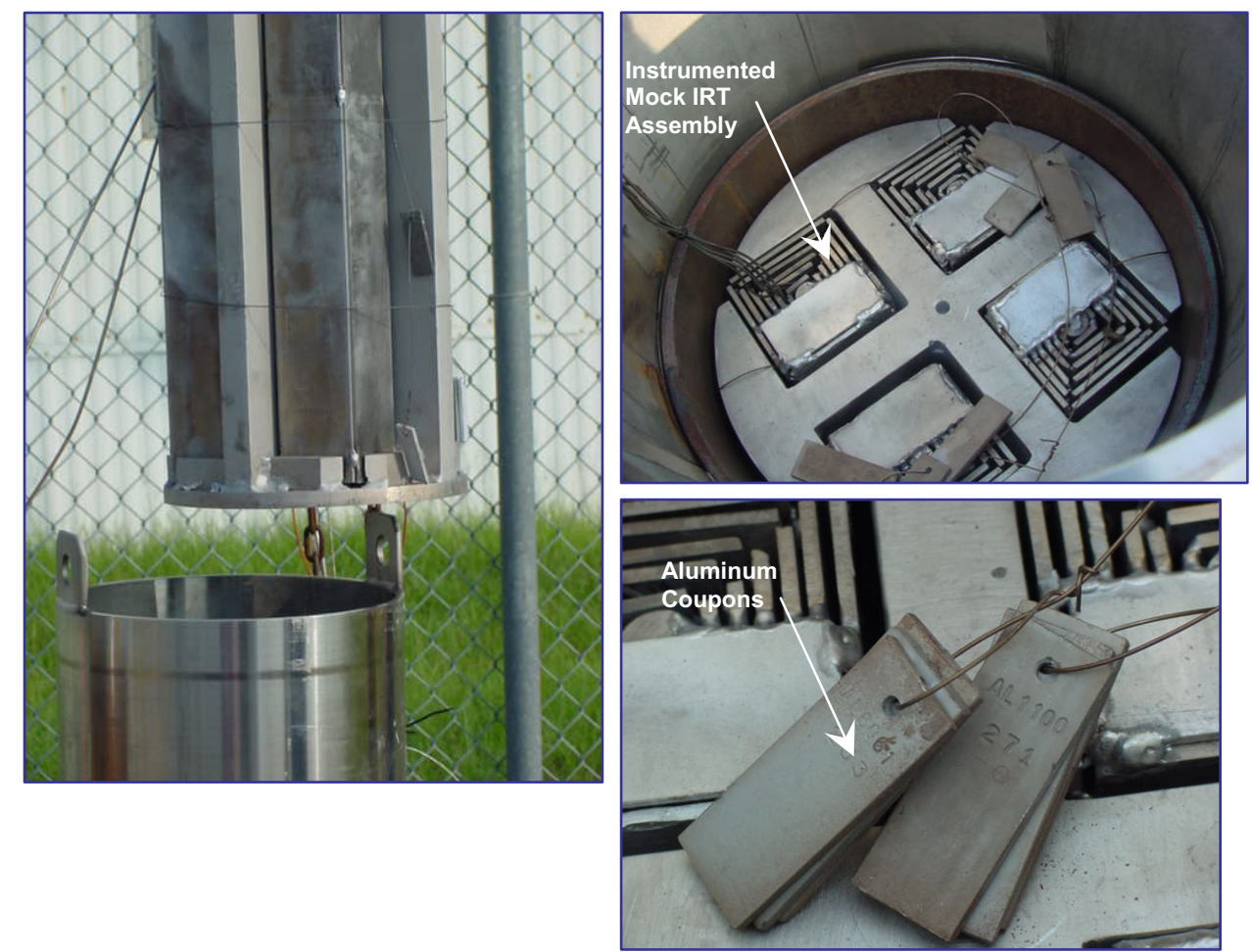

Figure 13 - Fuel Drying Test Arrangement

The furnace (with the load) was powered to $31 \mathrm{~kW}$ in Normal Mode. The PC data acquisition (DAQ) system interface functioned properly, but the interface module stopped working after 20 minutes. Power was removed from the coil until the interface module was operational again. Power $(20 \mathrm{~kW})$ was reapplied to the furnace and gradually turned down as the canister skin temperature approached its target temperature $\left(600^{\circ} \mathrm{C}\right.$ and later $\left.650^{\circ} \mathrm{C}\right)$. The target temperature for the fuel assemblies was $500^{\circ} \mathrm{C}$ which was approached cautiously. This method made the drying test last over 6 hours but produced the results shown in Figure 14. The graph indicates that all regions of the fuel assemblies remain fairly close in temperature (within $50^{\circ} \mathrm{C}$ ) with little overshoot if the canister temperature is increased slowly. This occurs as the energy from the canister and liner are transferred into the center of the load. The resulting temperature of thermocouples in the fuel was from $475^{\circ} \mathrm{C}$ to $525^{\circ} \mathrm{C}$. Comparing these with the published temperature [5] for water removal from hydrated oxides indicates that a 1 hour soak at these temperatures will remove $100 \%$ of water chemically bound in boehmite in addition to all the liquid and adherent vapor. 


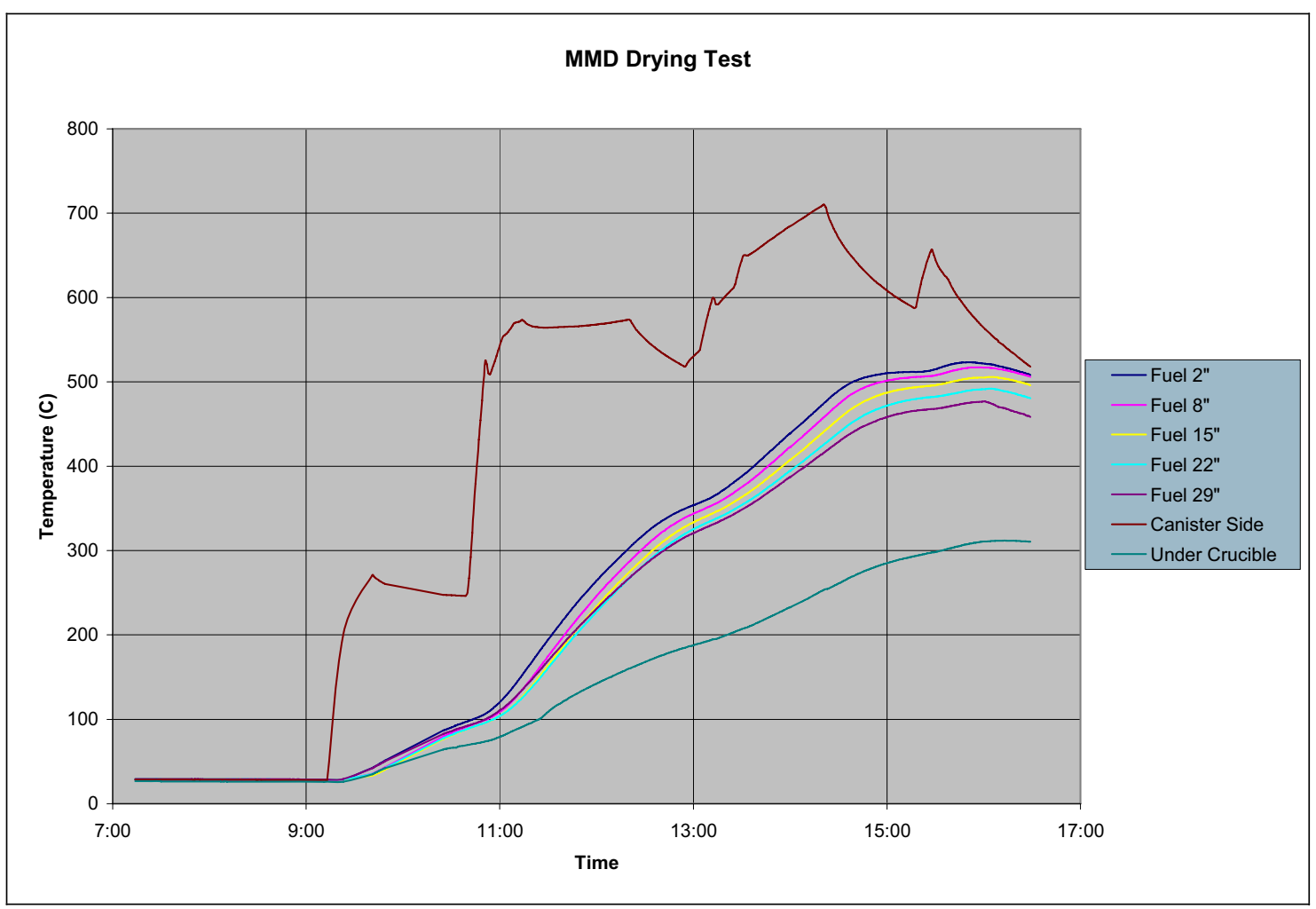

Figure 14 - Fuel Temperatures During Drying

Furnace power was turned off after reaching the target fuel temperature and soaking for a period. In order to minimize diesel generator running time, the shield plug was removed from the canister, the lift yoke was attached, and the canister was removed from the furnace. Two air lances were positioned to blow air into the crucible (which remained in the furnace cavity) until its temperature dropped below $200^{\circ} \mathrm{C}$, before the cooling fan was turned off.

Inspection of the fuel assemblies after cooling showed no melting of either the aluminum fuel basket or the surrogate fuel. In conjunction with the temperature information, this indicates furnace temperature control and the melt-container equipment will allow fuel drying without releasing fission-product gases targeted for entrapment in the sealed container. This has the benefit of maintaining the canister evacuation system as clean as possible. Very little discoloration was evident on the mock fuel or basket. Coupons attached to the fuel basket showed a range of surface effects: from nodules, to dark surface coloration, to no difference. Examples of these are shown in Figure 15. Note that a variety of aluminum alloys were used. Each had been weighed twice before being used in this test: once in the original condition and again after the hydrated oxide layer was grown on the surface. Table 4 indicates coupon alloys, weight gained during oxide growth, and weight lost during drying. Weight was lost from all coupons used in the test, in quantities that verify complete water removal. 

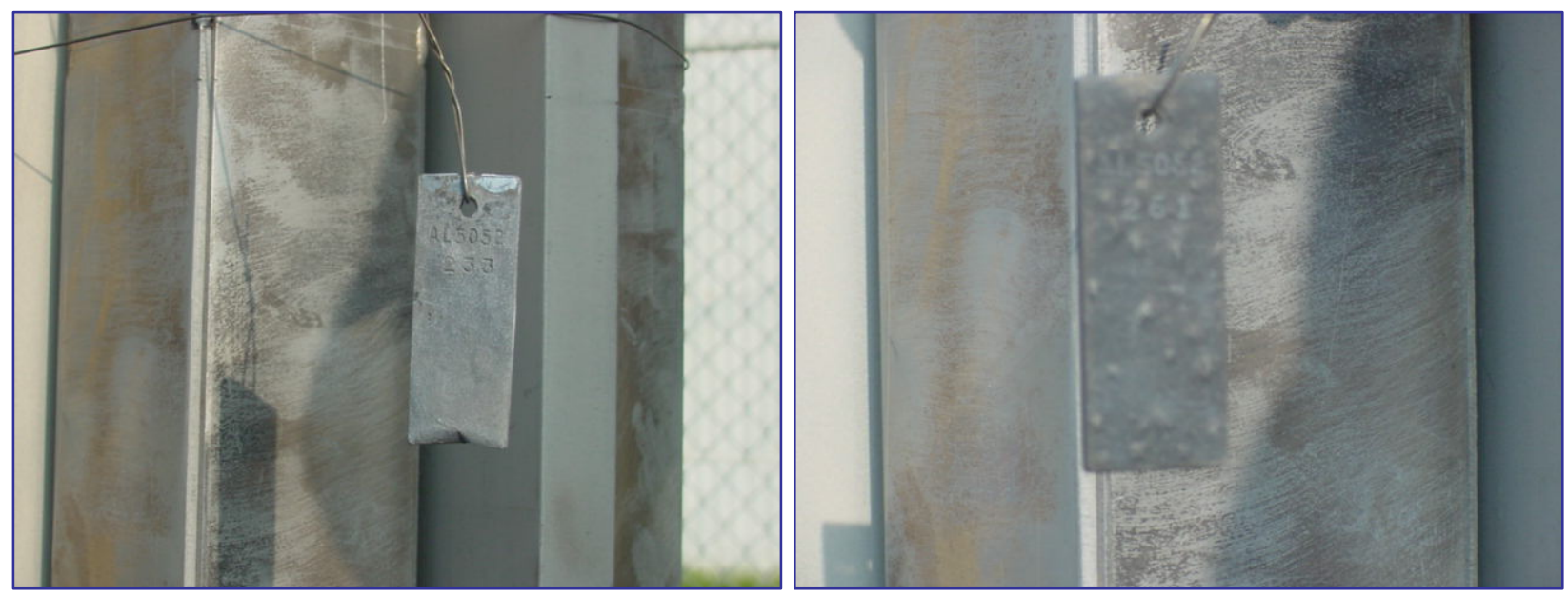

Figure 15 - Fuel Drying Coupons Following Drying Test

Table 4 - Fuel Drying Coupon Initial Weights \& Weight Loss

\begin{tabular}{|c|c|c|c|}
\hline Coupon \# & Coupon initial wt. (gms) & Wt. gain from oxide growth & Wt. loss from drying \\
\hline AL 6061 \#242 & 7.00452 & 0.01792 & 0.00436 \\
\hline AL 6061 \#247 & 7.23748 & 0.00837 & 0.00402 \\
\hline AL 6061 \#269 & 7.33215 & 0.03049 & 0.01028 \\
\hline AL $6061 \# 220$ & 6.95819 & 0.00835 & 0.00077 \\
\hline AL $6061 \# 233$ & 6.97029 & 0.03457 & 0.00323 \\
\hline AL 6061 \#261 & 7.6699 & 0.01381 & 0.00663 \\
\hline AL 5052 \#241 & 7.36417 & 0.01729 & 0.00183 \\
\hline AL 5052 \#268 & 7.5449 & 0.07701 & 0.01429 \\
\hline AL 5052 \#246 & 7.47259 & 0.02117 & 0.00074 \\
\hline AL $5052 \# 234$ & 7.5779 & 0.0831 & 0.01369 \\
\hline AL 5052 \#263 & 7.65481 & 0.01719 & 0.00466 \\
\hline AL 5052 \#261 & 7.57678 & 0.00686 & 0.0016 \\
\hline AL $5052 \# 233$ & 7.6442 & 0.02545 & 0.0048 \\
\hline AL $1100 \# 273$ & 7.15307 & 0.00851 & 0.00393 \\
\hline AL 1100 \#268 & 6.67972 & 0.02182 & 0.00251 \\
\hline AL $1100 \# 269$ & 7.21173 & 0.0181 & 0.00677 \\
\hline AL $1100 \# 293$ & 7.3329 & 0.05827 & 0.01294 \\
\hline AL $1100 \# 271$ & 7.18858 & 0.00739 & 0.00378 \\
\hline
\end{tabular}

These coupons demonstrated that complete water removal takes place at the correct temperature in a vented container with only natural convection. The evacuation system is still necessary to aid this process and remove air from the container so that a rough vacuum exists when it is sealed for actual fuel processing.

\subsection{TEMPERATURE CORRELATION}

Correlating fuel temperatures to an externally measurable temperature is necessary to allow the actual melt-dilute fuel processing to take place without breaking the canister seal for instrument connections. The MMD test canister was altered for these tests to allow instrument wires to pass 


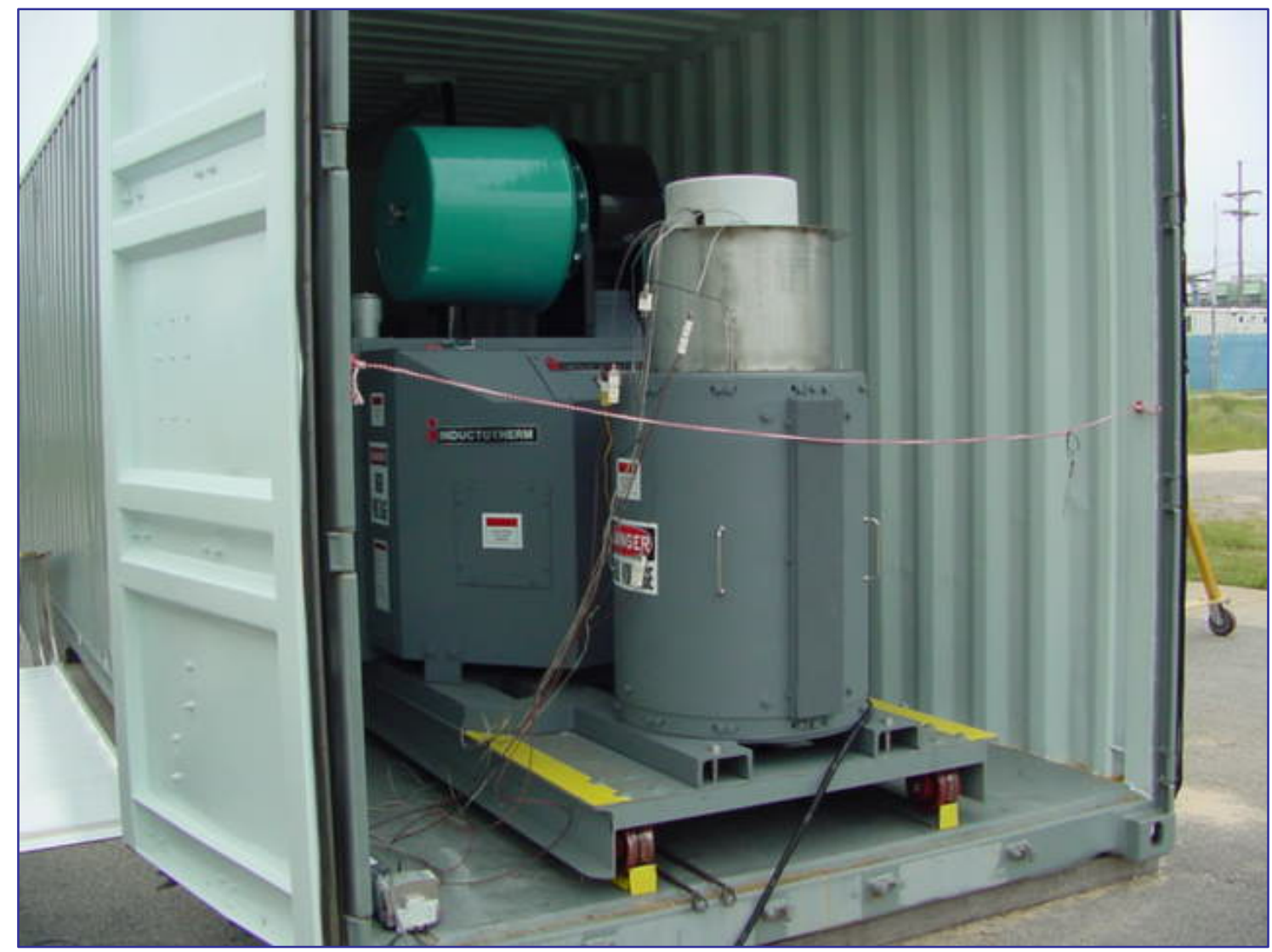

Figure 16 - Temperature Correlation Arrangement

into it (Figure 16). This meant the canister was not evacuated during the test, as described above and in the Test Plan [3]. Fuel placement symmetry allowed a single assembly to be instrumented during development tests. One of the four fuel assemblies was instrumented with 5 type $\mathrm{K}$ thermocouples and additional type $\mathrm{K}$ thermocouples were positioned on the outside of the canister and underneath the crucible. Figure 17 shows thermocouple placement. 


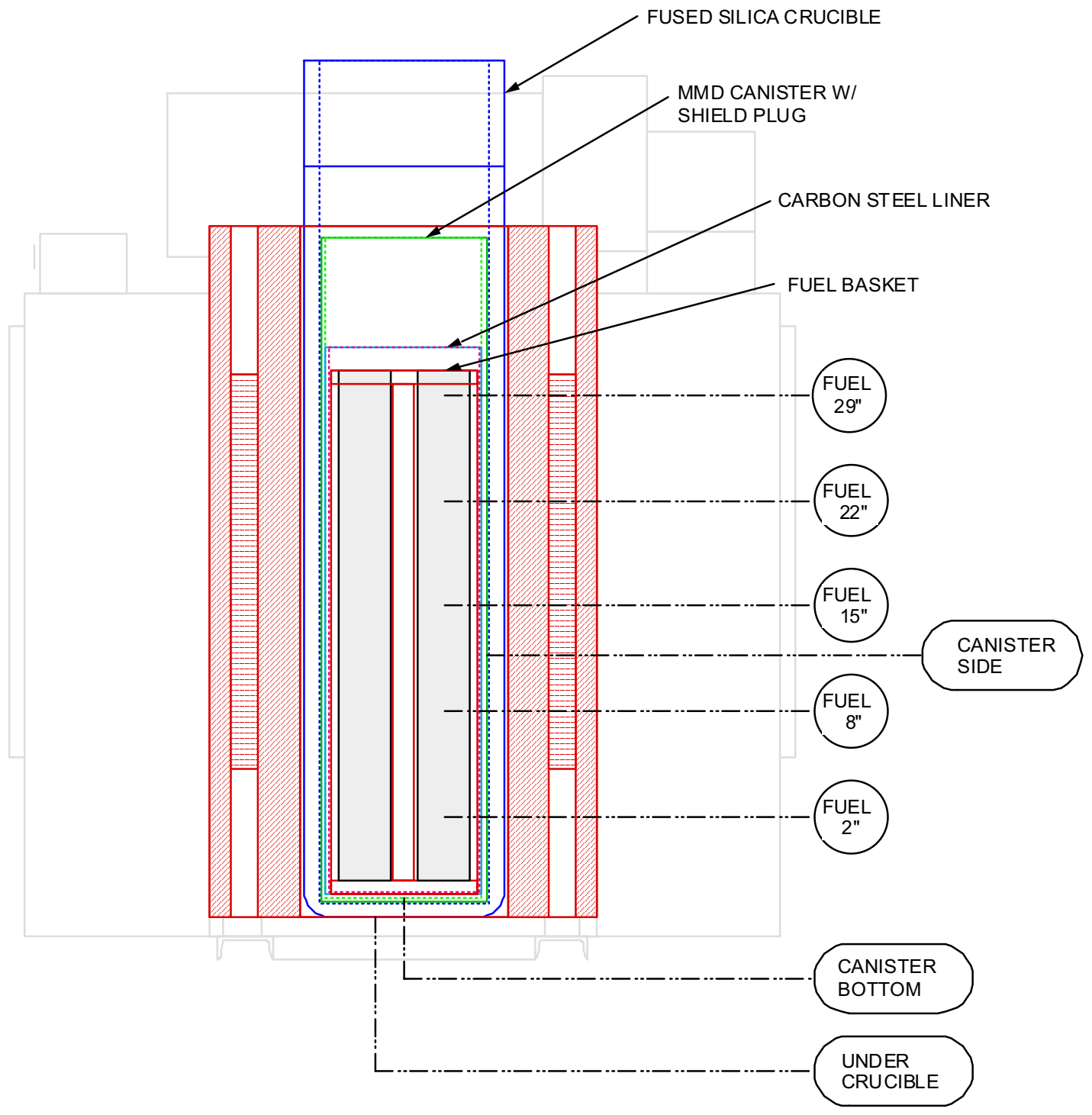

Figure 17 - Temperature Correlation Test Thermocouple Arrangement

The process sequence for this test involved bringing the fuel temperature to an average $500^{\circ} \mathrm{C}$ quickly, followed by a pause to simulate the drying and temperature equilibration. This was followed by a quick energy input until the canister's maximum temperature approached its limit $\left(815^{\circ} \mathrm{C}\right)$. Canister temperature was held slightly below this temperature for the remainder of the test. The canister and crucible thermocouples allowed a comparison of internal and external temperatures. Figure 18 shows the temperatures recorded during the test. This approach mimicked the melt-dilute thermal cycle, yet did not unduly stress the materials used. It produced data that is reckoned to approach the minimum drying and melting process time. 


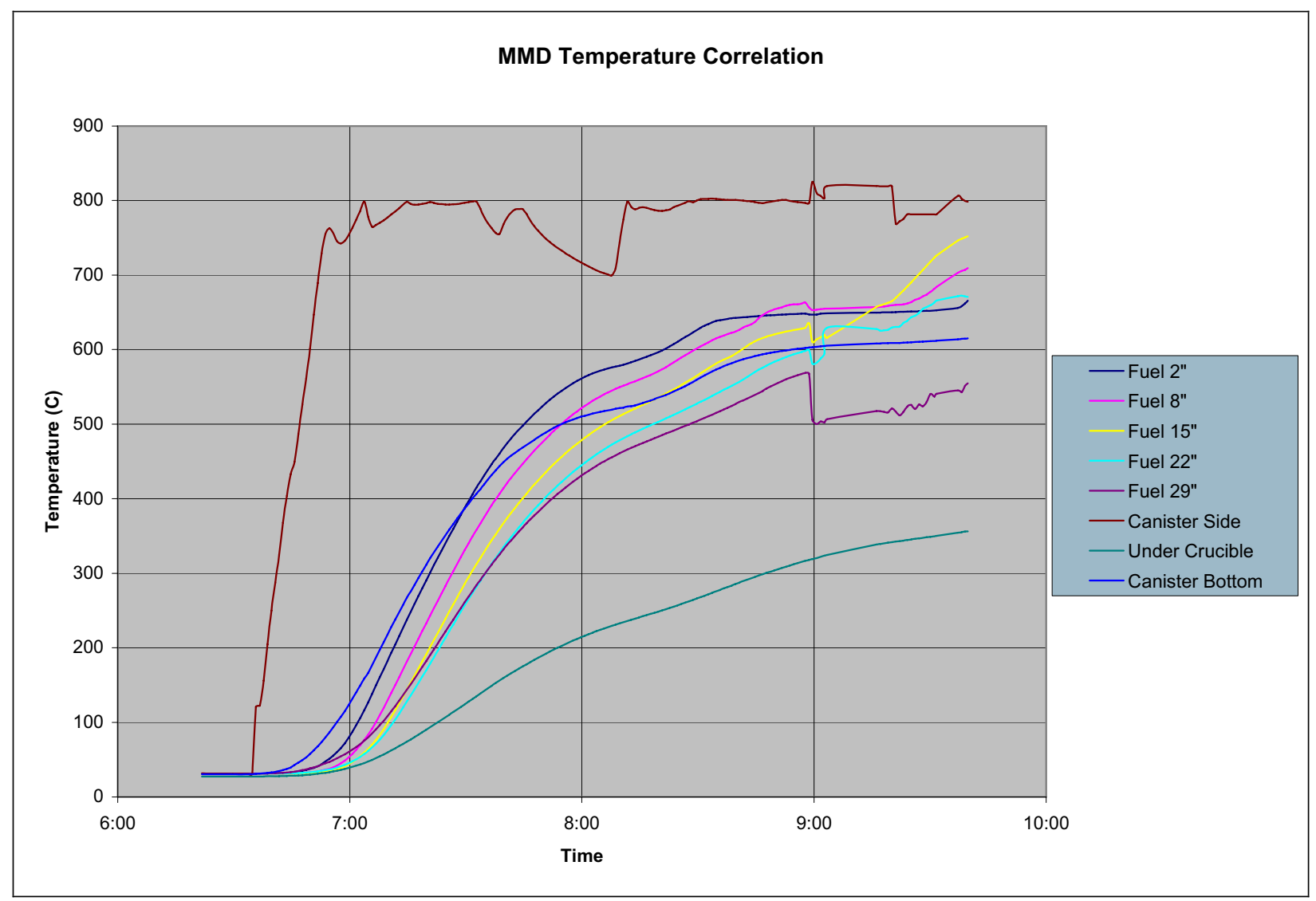

Figure 18 - Temperatures recorded during temperature correlation testing

The results show that fuel temperatures correspond closely with the canister bottom temperature. The rate of rise indicated by the 2" fuel thermocouple approaches zero, signaling the beginning of phase change in the fuel material, from solid to liquid. The rest of the fuel-mounted thermocouples followed later. As more energy was input, the percentage of solid fuel decreased until sudden temperature drops indicated some thermocouples lost contact with the fuel assemblies as they slumped down into the liner.

A number of important comparisons were made at this point including the relationship of the canister side and bottom temperatures to the molten fuel temperature, and the crucible temperature to the molten fuel temperature. The crucible temperature generally varies in proportion to fuel temperature and to the canister bottom temperature with very little time lag, but the proportion is not constant throughout the process. The crucible bottom does not give sufficient indication of the fuel phase change that occurs and is therefore of little use for control purposes.

The canister side wall temperature and fuel temperature do not correlate since the side wall is rapidly heated by the furnace and cools quickly as its energy is transferred to the liner, basket and fuel. It does not serve a control purpose. 
The canister bottom temperature also follows the fuel temperature directly and gives good indication of fuel temperature when the phase change begins. The difference between the two is dependent on heating rate and soak time (as applicable). During this period the lowest thermocouple (Fuel 2") on the fuel and the canister bottom stayed within $50^{\circ} \mathrm{C}$ of each other. After the fuel assemblies melted and the liquid metal temperature began to increase, the interface ceased to function correctly, so furnace power was shut down and the test brought to completion.

The shield plug was removed and 2 air lances were positioned to cool the liquid metal. When its surface froze, the canister lifter was attached and the canister was removed from the furnace and placed outside the ISO container to cool. The air lances were directed into the crucible and it was cooled below $200^{\circ} \mathrm{C}$ before the cooling fan was turned off. Again, the purpose of these steps was to minimize time on the diesel generator.

The furnace power levels were recorded each time they were changed to facilitate characterization of the furnace in relation to the process. This allowed power input to be integrated over each segment of the test and summed over chosen portions of the process. This is less direct than temperature measurement and could be useful as a check on the process, but would not be considered as a primary method for control.

\subsection{MELT STIRRING / INTEGRATED SYSTEM}

Melt Stirring was combined with the Integrated System test described in the Test Plan [3], since a typical surrogate fuel load would be necessary to conduct a normal melt sequence and evaluate stirring. The furnace load duplicated the standard equipment and load used in the Temperature Correlation test, and heating followed the same pattern.

Power was applied to the furnace coil in the Normal Mode, heating the canister surface to its maximum operating temperature. This surface temperature was held until the fuel reached its drying temperature and slightly more than an hour of soak time (at $500^{\circ} \mathrm{C}$ to $580^{\circ} \mathrm{C}$ ) was allowed to duplicate fuel drying time. During this period, the canister surface temperature dropped noticeably $\left(175^{\circ} \mathrm{C}\right)$ as heat was transferred to its interior. This was followed by a rapid ramp to maximum canister surface temperature, $800^{\circ} \mathrm{C}$, and that temperature was held while the fuel melted and was superheated. Note the flat region of the 2 " fuel thermocouple (TC) curve and canister bottom TC curve in Figure 17 between 10:30 and 11:45. This flat region indicates that the latent energy of fusion was being absorbed by the aluminum load as it changed state from solid to liquid. The crucible cover and shield plug were removed when the molten fuel reached $750^{\circ} \mathrm{C}$, and 7.6 pounds of the surrogate diluting agent, copper, was introduced into the melt. Copper is similar to uranium in its solubility in molten aluminum. 


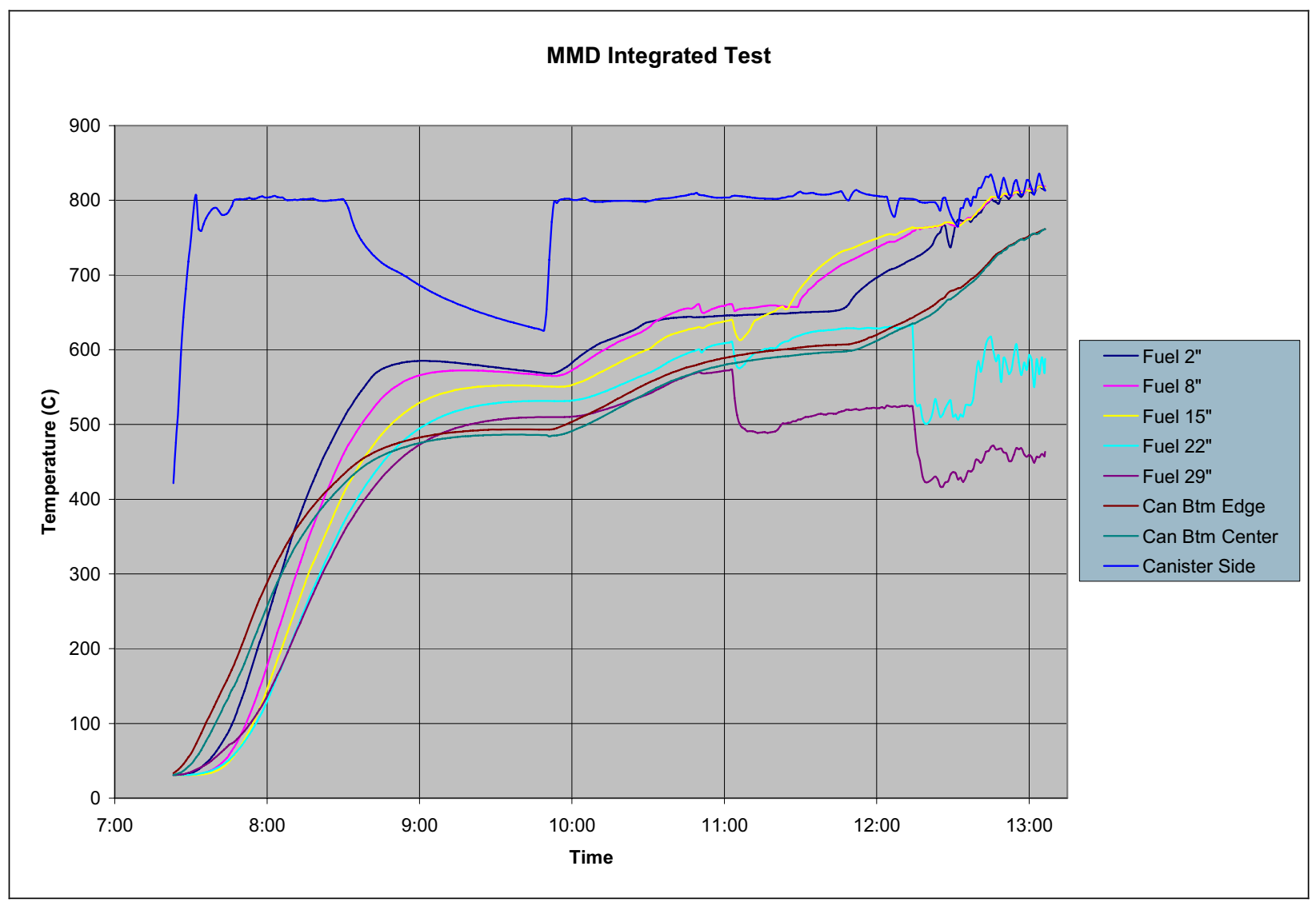

Figure 19 - MMD Integrated Test Temperature History

DEH stirring frequency was set at $1 \mathrm{~Hz}$, power level at $25 \mathrm{~kW}$, and duration at 2 minutes. This cycle was repeated 7 times, and the metal surface was photographed. The furnace power was subsequently turned off. Figure 19 shows the temperature data recorded during the integrated test. All heating and control equipment functioned correctly.

The canister side TC temperature is the top curve on the plot and is a good indicator of when power was applied to the coil and when it was turned down or off. No temperature overshoot took place with this furnace-load combination. Canister bottom center and canister bottom edge thermocouples followed the fuel temperature with a $50^{\circ} \mathrm{C}$ offset once the fuel and basket were completely molten. As expected, some thermocouples lost contact with the molten aluminum i.e., fuel 22 " TC and fuel 29" TC when the fuel melted and slumped away from them. They continued to be influenced by the radiant heat from the molten aluminum, liner wall, air in the container, and the power input during stirring.

When stirring was complete, furnace power was turned off and cooling began. Due to the long cooling cycle in the furnace, forced-air cooling of the canister was used again to accelerate the cooling process. The solidified ingot was removed from the canister and cut into wafers. Copper added to the molten fuel assemblies was entirely melted and incorporated into the ingot. DEH modulated induction stirring was effective in accelerating dilution and keeping the melt and dilute process duration under 4 hours. 

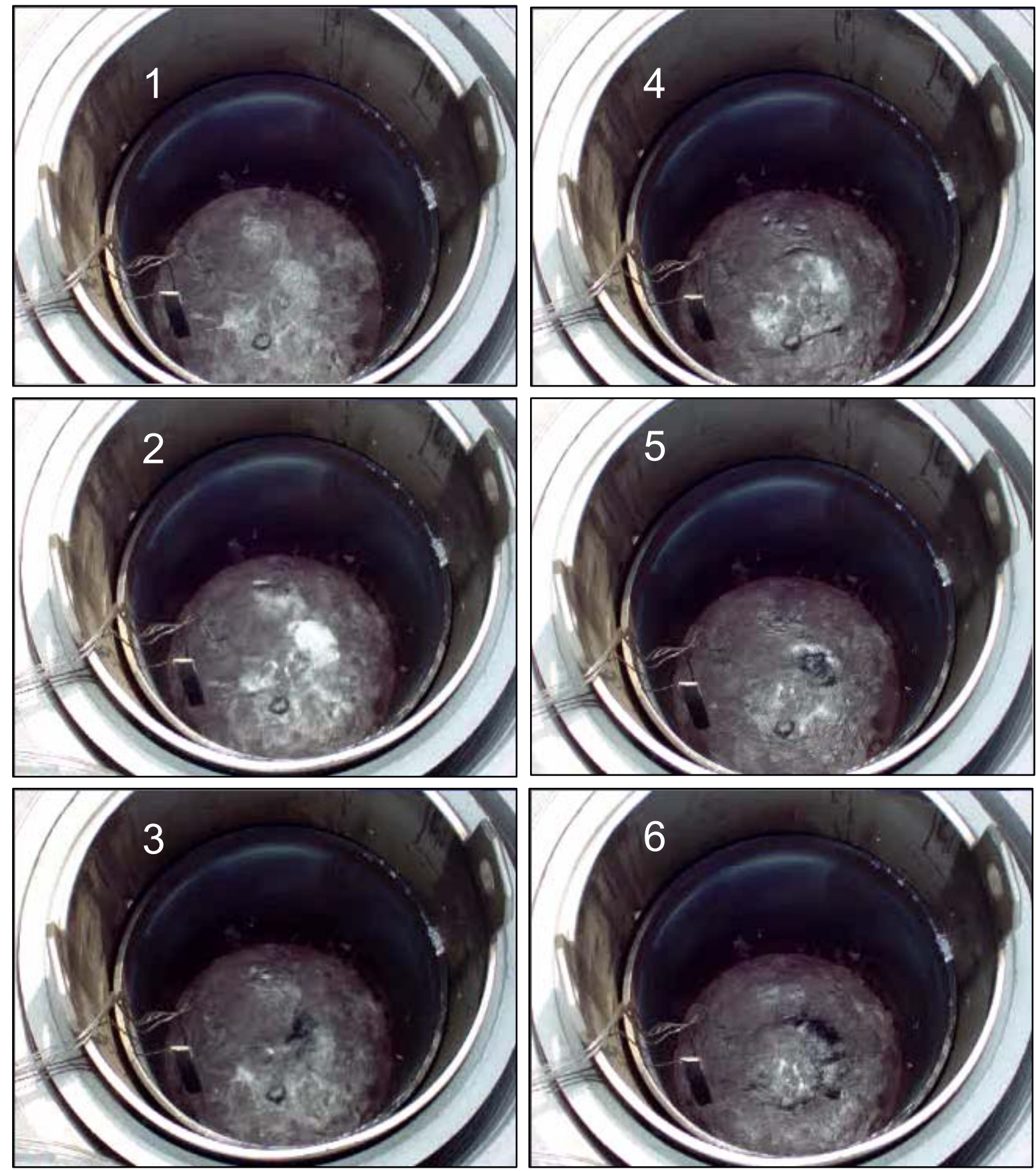

Figure 20 - Visual Verification of Magnetic Stirring 


\subsection{CONCLUSION}

Testing was completed as described in the Test Plan [3] for FY 05. Furnace use in testing indicates that it is easily operated via the remote pendant to perform the necessary functions of drying, melting, and stirring. Testing indicated that temperature can be controlled with minimal instrumentation of the canister, and that there is a direct and consistent correlation of canister's bottom surface temperature to fuel assembly core temperature. It follows that the drying process can be performed, followed by the corresponding melting and stirring without the need to penetrate the canister's surface for instrument wires.

The acquired data also showed that the furnace is easily controlled to avoid exceeding operating limits and that heating continues during the stirring cycle so excessive superheating is unnecessary. Operational experience gained during system tests indicated the benefits to accelerated canister cooling. In radioactive service, the canister can interface with the transport cask when its contents are solid and cool enough to avoid damaging the transfer cask equipment (grapple, shielding).

The commercial canister connection port fitting prototypes failed the pre-test helium leak check, so canister tests under MMD drying conditions could not be performed. The manufacturer was notified of the problem with the prototypes. The manufacturer is in the process of evaluating the fitting design for the necessary modifications. Further evaluation of the quick disconnects will be necessary in the future.

The canister performed as designed during its qualification testing. The canister maintained its structural integrity and the canister's containment boundary was not breeched during any of the qualification tests.

The power source, furnace, and canister systems performed well and as designed. No problematic characteristics were discovered. The fundamental process is supported by a sound system design. 


\subsection{REFERENCES}

1. Mobile Melt-Dilute Technology Development Project: Prototype Canister Design, Prepared Jointly by Idaho National Laboratory and Savannah River National Laboratory, FSU-0172-ES-01, March 31, 2005.

2. Mobile Melt-Dilute Technology Development Project: Uranium/Aluminum Dissolution Testing, Prepared Jointly by Argonne National Laboratory and Savannah River National Laboratory, FSU-0168-ES-00, September 20, 2004.

3. Mobile Melt-Dilute Technology Development Project: FY 2005 Testing Plan, Prepared Jointly by Idaho National Laboratory and Savannah River National Laboratory, FSU-0178-ES-01, December 2, 2004.

4. Mobile Melt-Dilute (MMD) Technology Development Project, Canister Connection Port Options Study, Revision 0, September 3, 2004

5. Emittance of Boehmite and Alumina Films on 6061 Aluminum Alloy Between 295 and 773 K, Kollie, Radcliff, and Weaver, Journal of Heat Transfer, Feb. 1991. 


\subsection{PROTOTYPE TEST PHOTOS AT SRNL}

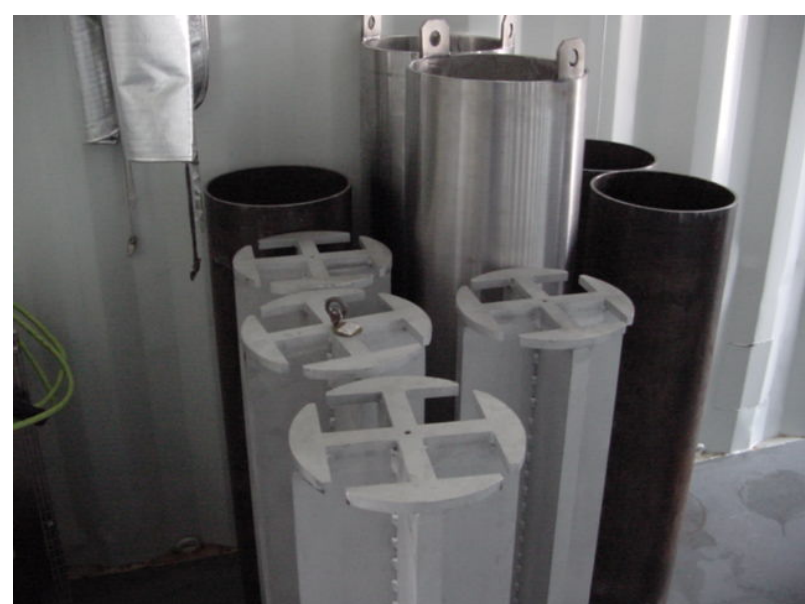

Fuel Baskets, Liners \& Canisters

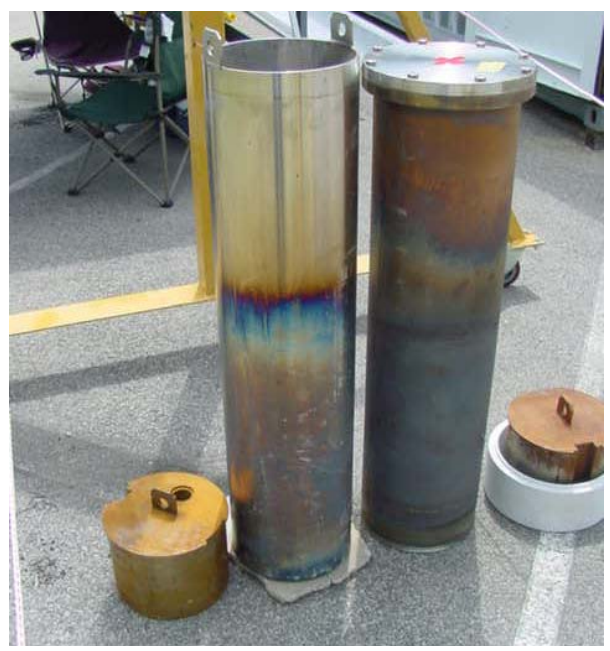

Canister \& Shield Plug

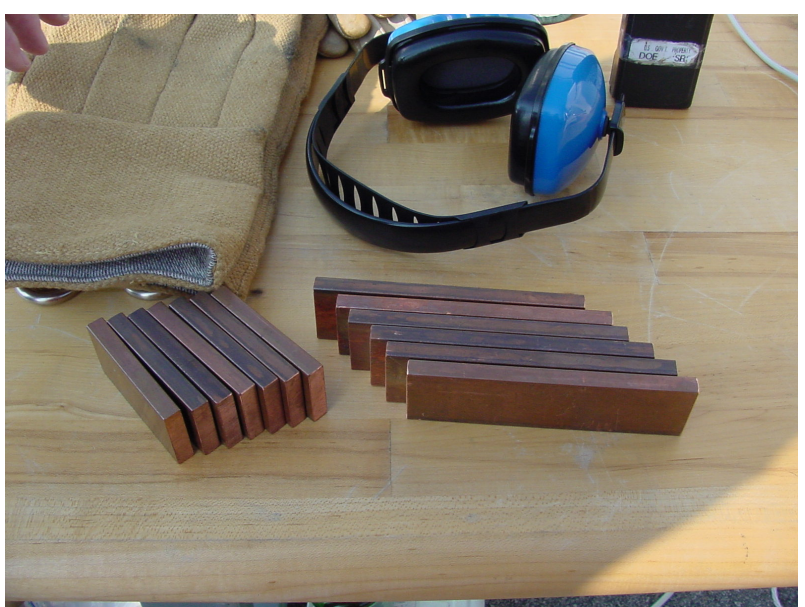

Copper used in Stirring Test

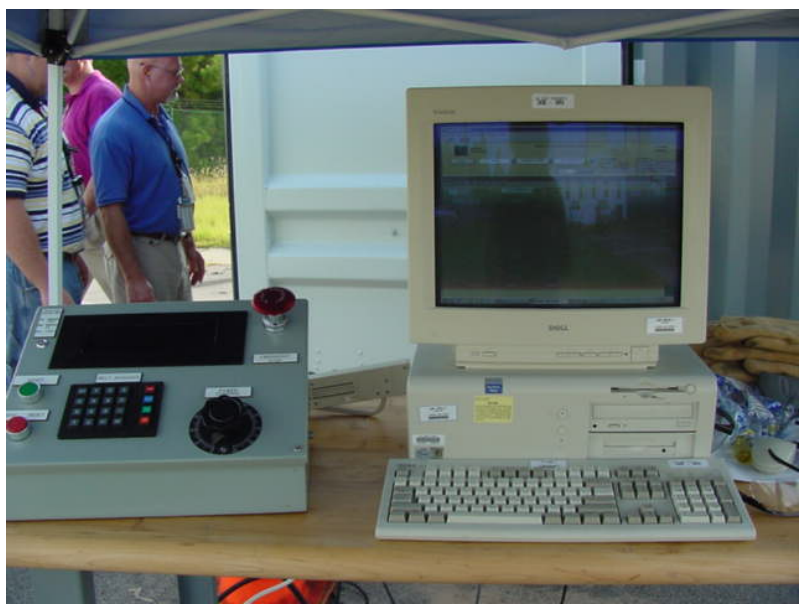

Furnace Remote Pendant \& Data Acquisition PC 


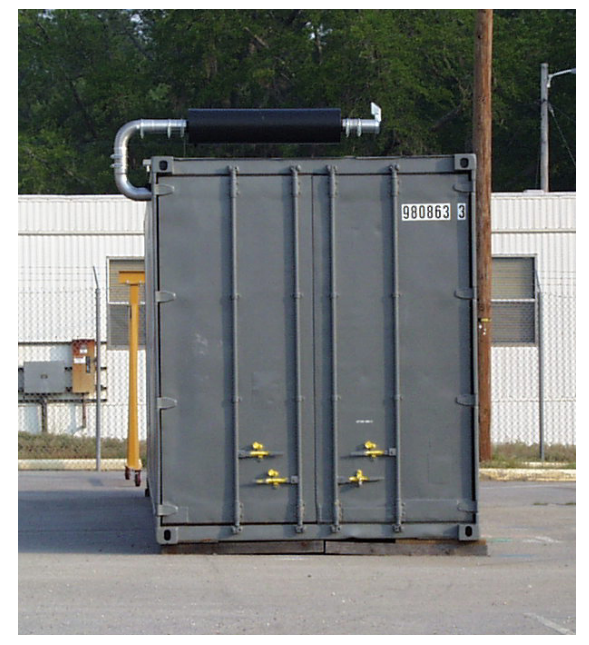

ISO w/Exhaust

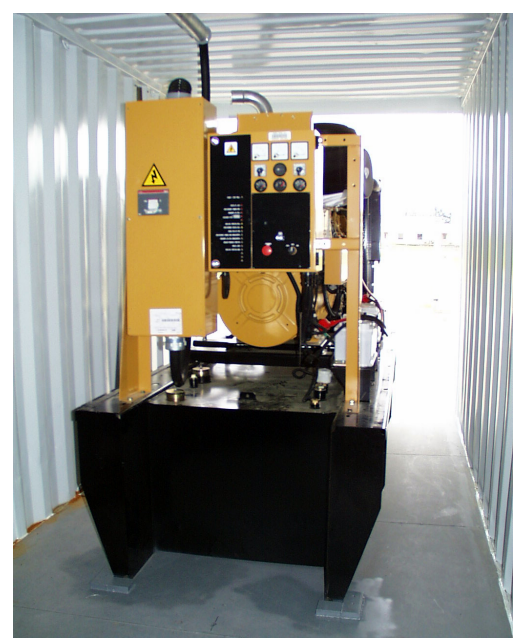

Diesel Generator

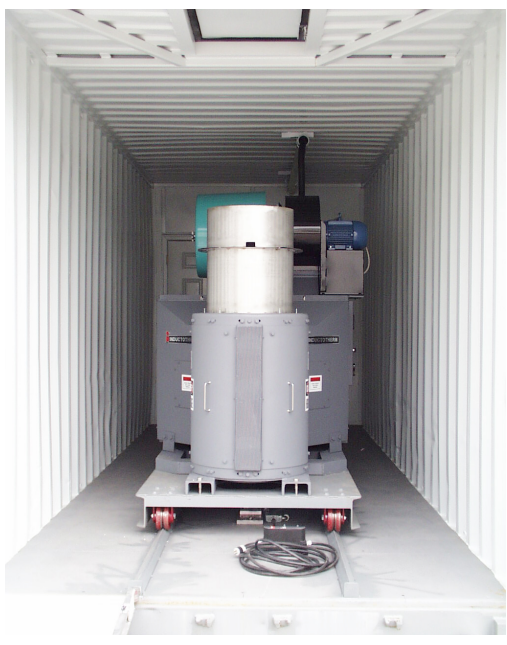

DEH Furnace on Cart

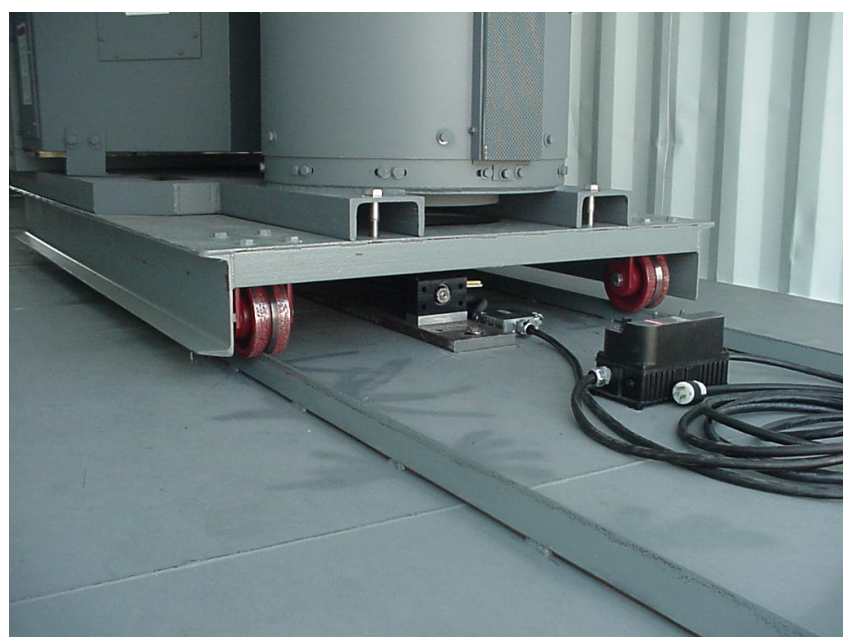

Furnace Cart, Rails \& Drive System 

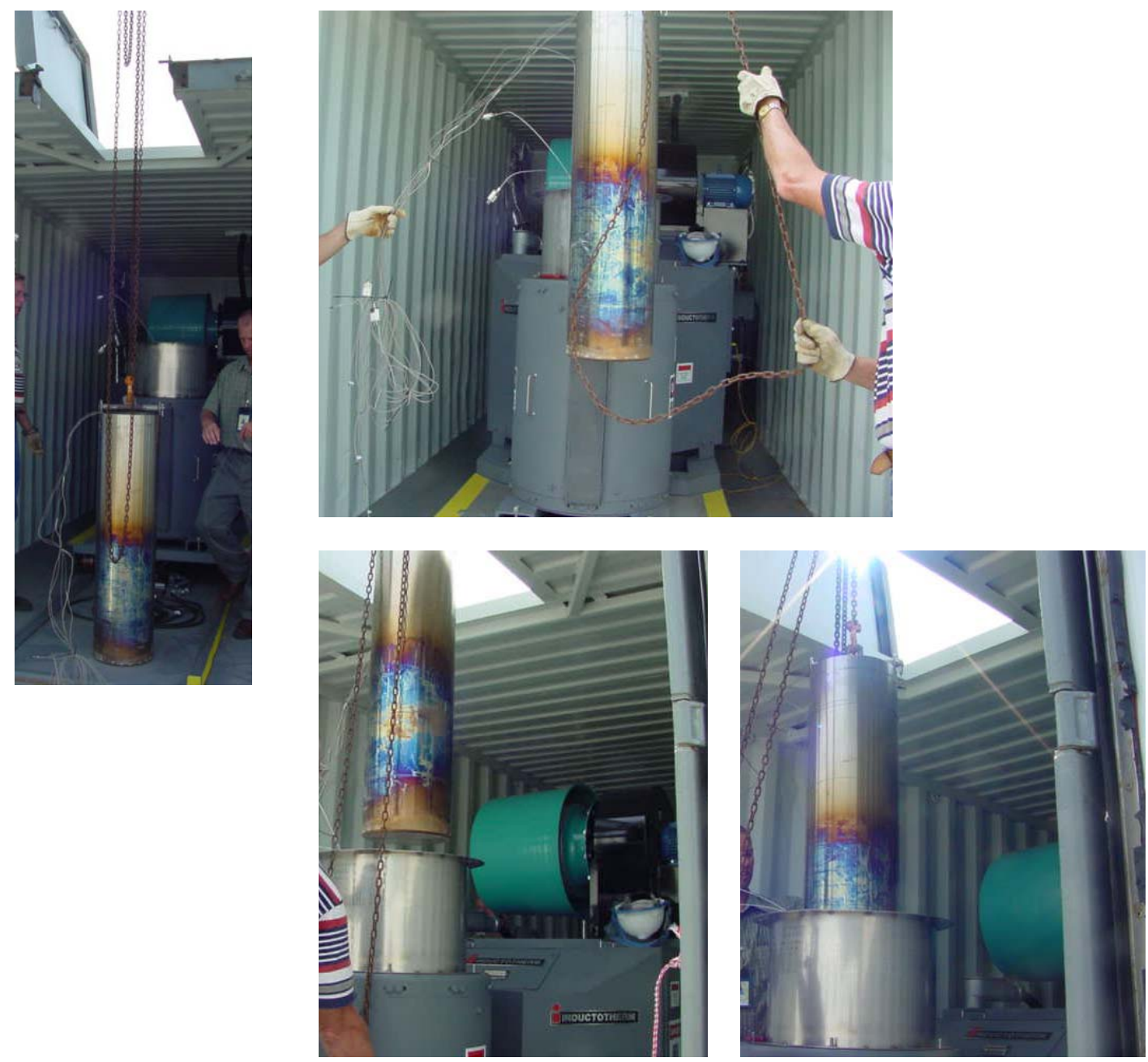

Loading Canister into DEH Furnace 